\title{
Working
}

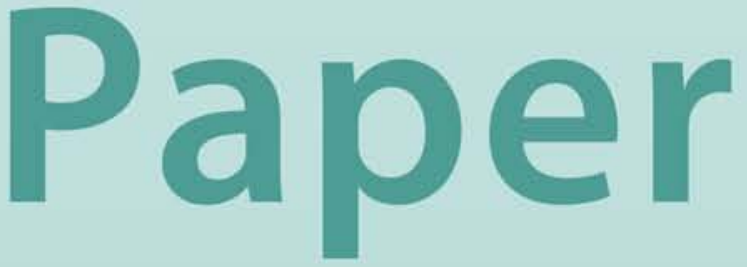


Rapid Credit Growth: Boon or Boom-Bust?

Selim Elekdag and Yiqun Wu 


\title{
IMF Working Paper
}

Asia and Pacific Department

\section{Rapid Credit Growth: Boon or Boom-Bust?}

Prepared by Selim Elekdag and Yiqun Wu

Authorized for distribution by Roberto Cardarelli

October 2011

\section{This Working Paper should not be reported as representing the views of the IMF.} The views expressed in this Working Paper are those of the author(s) and do not necessarily represent those of the IMF or IMF policy. Working Papers describe research in progress by the author(s) and are published to elicit comments and to further debate.

\begin{abstract}
Episodes of rapid credit growth, especially credit booms, tend to end abruptly, typically in the form of financial crises. This paper presents the findings of a comprehensive event study focusing on 99 credit booms. Loose monetary policy stances seem to have contributed to the build-up of credit booms across both advanced and emerging economies. In particular, domestic policy rates were below trend during the pre-peak phase of credit booms and likely fuelled macroeconomic and financial imbalances. For emerging economies, while credit booms are associated with episodes of large capital inflows, international interest rates (a proxy for global liquidity) are virtually flat during these periods. Therefore, although external factors such as global liquidity conditions matter, and possibly increasingly so over time, domestic factors (especially monetary policy) also appear to be important drivers of real credit growth across emerging economies.

JEL Classification Numbers: E32; E44; E51; F30; F44; G21
\end{abstract}

Keywords: credit; credit booms; boom-bust cycles; financial crises; emerging Asia Authors’ E-Mail Address:selekdag@imf.org, ywu2@imf.org 


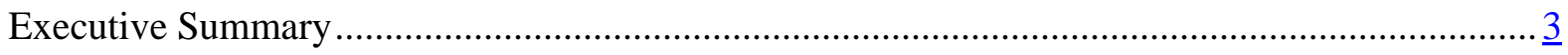

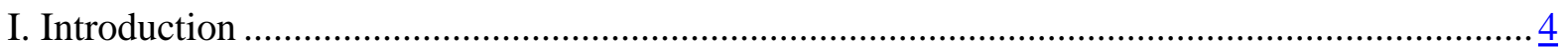

II. How are Credit Booms Identified? ................................................................................ $\underline{6}$

A. Identifying Credit Booms: An Example .................................................................... $\frac{7}{8}$

B. Focusing Only on Bank Credit Could Yield Misleading Policy Implications...................... $\underline{8}$

III. What Do Credit Booms Look Like? ............................................................................... $\underline{9}$

IV. The Dynamics of Credit Booms …......................................................................... 10

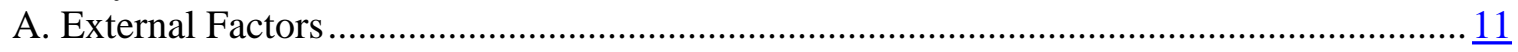

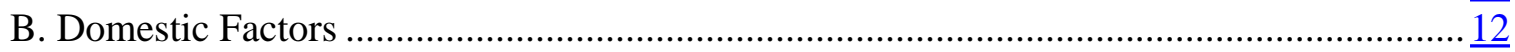

V. 99 Credit Balloons .................................................................................................. 16

A. Credit Booms Across Advanced and Emerging Economies …...................................... 17

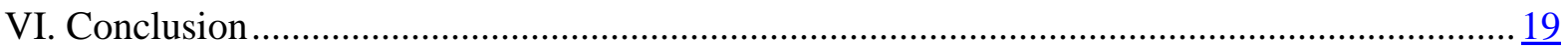

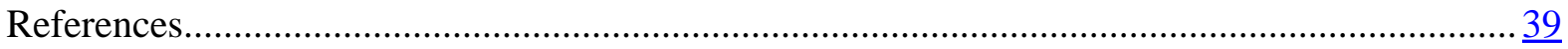

Figures

1. Nominal Credit to Private Sector ................................................................................ 24

2. Crises Associated with Emerging Market Credit Booms ................................................... 24

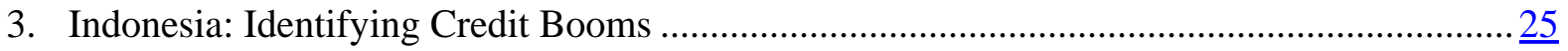

4. Korea: Identifying Credit Booms ..............................................................................

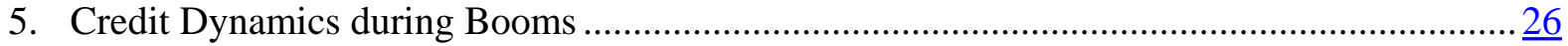

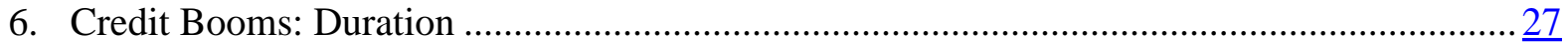

7. Peaks of Credit Booms Over Time................................................................................... 27

8. Credit Booms in Emerging Economies Associated with Episodes of Capital Inflows ........... 27

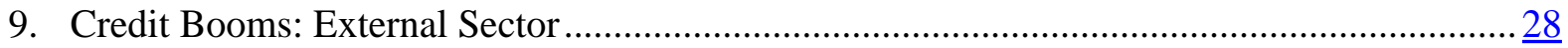

10. Credit Booms: Real Sector ...................................................................................... 29

11. Credit Booms: The Role of Policies .......................................................................... $\underline{30}$

12. Credit Booms and Financial Instability ......................................................................

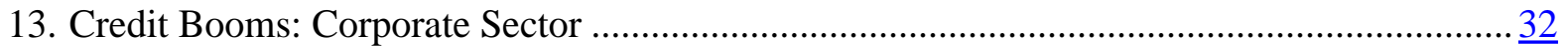

14. Advanced versus Emerging Economics: Real Sector....................................................... $\underline{33}$

15. Advanced versus Emerging Economics: Real GDP .......................................................

16. Advanced versus Emerging Economics: External Sector ……........................................ $\underline{35}$

17. Advanced versus Emerging Economics: The Role of Policies .......................................... $\underline{36}$

18. Advanced versus Emerging Economics:Credit Booms and Financial Instability ................... $\underline{37}$

19. Advanced versus Emerging Economics: Corporate Sector .............................................. $\underline{38}$

Tables

1. Credit Booms, Capital Inflows, and Crises …............................................................ 20

2. Rapid Credit Growth and Booms ……........................................................................ 23

3. Credit Booms Associated with Crises ..................................................................... $\frac{23}{23}$

4. Pre-Peak Credit Growth ............................................................................................ 


\section{Executive Summary}

This paper is motivated by rapid credit growth across many emerging economies, particularly those in Asia. It presents the results of a comprehensive event study which identifies 99 credit booms, of which 39 and 60 originated in advanced and emerging economies, respectively. Episodes of excessive credit growth—credit booms—-lead to growing financial imbalances, and tend to end abruptly, often in the form of financial crises. In particular, relative to booms in other emerging economies, credit booms in emerging Asia were associated with a higher incidence of crises historically.

Three other main conclusions include the following:

- $\quad$ First, as credit booms build, they are jointly associated with deteriorating bank and corporate balance sheet soundness, and symptoms of overheating including: large capital inflows (including less stable bank flows), widening current account deficits, buoyant asset prices, and strong domestic demand.

- $\quad$ Second, while credit booms are associated with episodes of large capital inflows, international interest rates (a proxy for global liquidity), are virtually flat during these periods, which suggests the important role of domestic factors in driving credit growth across emerging economies. This may reflect, in part, that capital inflows are being channeled into other asset classes including real estate, equity, and corporate bonds, for example.

- $\quad$ Third, loose macroeconomic policy stances seem to have contributed to the build-up of credit booms. In particular, this seems to be the case for monetary policy across both advanced and emerging economies. For emerging economies, while international interest rates were essentially flat, domestic policy rates were below trend during the pre-peak phase of credit booms. Therefore, although external factors such as global liquidity conditions matter, and possibly increasingly so over time, domestic factors (especially monetary policy) also appear to be important drivers of real credit growth across emerging economies including those in Asia. 


\section{INTRODUCTION}

Episodes of excessive credit growth are often associated with periods of financial and macroeconomic instability. Since 2009, credit growth, despite some recent moderation, has been rapid in many emerging economies. This is especially true in many Asia economies, where credit growth is still at relatively high levels (Figure 1).

Credit can grow rapidly for at least three reasons: financial deepening (shown to support growth, Levine, 2005), normal cyclical upswings (the demand and availability of credit tends to increase during recoveries), and excessive cyclical fluctuations (“credit booms”). Episodes of rapid credit growth, especially credit booms, are typically associated with growing financial imbalances, and tend to end abruptly, often in the form of financial crises. In fact, historically, Asian credit booms have been characterized by a higher incidence of crises relative to all other emerging economies, including banking, currency, and debt crises (Figure 2). ${ }^{1}$

Against this background, this paper focuses on the following questions:

- When is an episode of rapid credit growth more likely to be associated with excessive financial imbalances?

- What are credit booms, what do they look like, and what are the main domestic and external drivers of credit booms?

- $\quad$ Relatedly, what are the main warning signs that help distinguish booms that ended more smoothly versus those that ended in disruptive credit boom-busts?

- What are the main policy implications?

To address these questions, this paper focuses on credit booms, which are broadly periods of excessive credit growth. Using an event study, and based on annual macroeconomic, financial, corporate- and banking-level data from 1960-2010, 99 credit booms are identified across 21 advanced and 43 emerging economies. The first part of the paper concentrates on emerging economies, occasionally focusing on emerging Asia, while the second part of the paper takes a more global perspective and utilizes the information contained in all of the 99 credit booms identified.

The main findings are summarized as follows:

- $\quad$ First, as credit booms build, they are jointly associated with deteriorating bank and corporate balance sheet soundness, and symptoms of overheating including: large

\footnotetext{
${ }^{1}$ Crisis dates are based on Reinhart and Rogoff (2009), also see Table 1.
} 
capital inflows (including less stable bank flows), widening current account deficits, buoyant asset prices, and strong domestic demand.

- $\quad$ Second, while credit booms are associated with episodes of large capital inflows, international interest rates (a proxy for global liquidity) are virtually flat during these periods, which suggests the important role of domestic factors in driving credit growth across emerging economies. ${ }^{2}$

- $\quad$ Third, loose macroeconomic policy stances seem to have contributed to the build-up of credit booms. In particular, this seems to be the case for monetary policy across both advanced and emerging economies. For emerging economies, while international interest rates were essentially flat, domestic policy rates were low during the pre-peak phase of credit booms. Therefore, although external factors such as global liquidity conditions matter, and possibly increasingly so over time, domestic factors (especially monetary policy) also appear to be important drivers of real credit growth across emerging economies including those in Asia.

In contrast to some related studies, along with the emphasis on the role of macroeconomic policies, this paper makes several other contributions to the literature, which include the emphasis of the following:

- $\quad$ First, the rapid rise in nonbank intermediation poses a challenge in detecting booms, implying that the perimeter of financial supervision should be widened to ensure financial imbalances are detected early.

- $\quad$ Second, by tracking the composition of bank liabilities, it is possible to infer the state of the financial cycle, which could help uncover looming vulnerabilities earlier on. In particular, booms which ended in disruptive credit busts are more closely associated with rapid increases in bank nondeposit liabilities, funded through increased foreign currency-denominated liabilities via capital inflows (which can be in the form of less stable banks flows).

- $\quad$ Third, within the context of credit booms across both advanced and emerging economies, evidence suggests that price stability may not ensure financial stability.

\footnotetext{
${ }^{2}$ It is important to underscore the important role of domestic factors in driving credit growth, and not capital inflows. While credit booms appear to be tightly linked to episodes of large capital inflows, there are other asset classes which are also likely absorbing these inflows including real estate, equity (both public as monitored on exchanges, but also private equity), FDI (related to equity, but also "green-field" FDI which is associated with physical capital accumulation), fixed income securities (for example, corporate bond issuance), and credit which linked to nonfinancial institutions or off-balance sheet vehicles (which are more difficult to monitor).
} 
It should be recognized that these findings are based on an event study identifying credit booms using data that goes back to 1960 for many countries. While event studies can be very useful in terms of uncovering important stylized facts-particularly revealing key nonlinear relationships - the results here should not be interpreted as having any causal implications. To take up the issue of causality more seriously, a structural model is needed, which is the next step in this research agenda.

This paper represents a synthesis of other studies focusing on financial imbalances, and, in particular, those related to rapid credit growth. For example, Mendoza and Terrones (2008) propose a methodology for measuring credit booms that this paper adheres to closely. They try to offer an alternative procedure to that developed by Gourinchas and others (2001), one of the first comprehensive papers focusing on credit booms (also referred to as lending booms in some studies). Tornell and Westermann (2002), is similar in spirit to both papers just mentioned, whereas Barajas and others (2011) try to differentiate between booms ending smoothly in contrast to those which ended abruptly. Other papers have focused on credit booms, including a recent paper by Decressin and Terrones (2011), which highlights that capital inflows are good predictors of credit booms. Covering a period of about 140 years, Jorda and others (2010) focus on interplay between credit booms, crises and external imbalances, while Schularick and Taylor (2010) also take a historical perspective and consider the role of monetary policy. While this paper occasionally focuses on credit booms in emerging Asia, other studies have considered other regions. For credit cycles in advanced economies, see, for example, Claessens and others (2011). For other emerging market regions, Bakker and Gulde (2010) and Barajas and others (2010) concentrate on Europe and Middle East and North Africa, respectively. Because excessive credit growth is a financial imbalance, this paper is related to numerous other empirical and theoretical studies which are related to the broad issue of financial instability. Therefore, rather than attempt to summarize this vast literature here, the most relevant studies are cited throughout the paper.

\section{HoW ARE CREDIT BoOMS IDENTIFIED?}

Credit booms are episodes during which real credit to the private sector expands substantially faster than what has been observed in previous expansions. To determine the occurrence of a credit boom, a pattern recognition algorithm is implemented using annual data going back to $1960 .^{3}$ Specifically, a credit boom occurs when the deviation of real credit from trend is in the upper tail of the distribution. ${ }^{4}$ More precisely, similar to Mendoza and Terrones (2008), a

\footnotetext{
${ }^{3}$ Pattern recognition algorithms are not uncommon in macroeconomics, and are used to date business cycle turning points. In fact, while the National Bureau of Economic Research (NBER) officially dates peaks and troughs, and therefore determines recession periods in the United States, the pioneering work by Burns and Mitchell (1946), can be replicated by algorithms as discussed in Bry and Boschan (1971) and Harding and Pagan (2002).

${ }^{4}$ Four main databases are used in this study: (1) the IMF's IFS data base, (2) the IMF's World Economic Outlook database, (3) the BankScope database for bank-level data, and (4) the WorldScope database for firm-
} 
credit boom occurs when the cyclical component of real credit is larger than 1.55 times its standard deviation (an event in which the deviation of real credit from trend is in the top $6^{\text {th }}$ percentile of the distribution). While Mendoza and Terrones (2008) use a value of 1.75 to determine the threshold, this papers considers a baseline threshold value of 1.55 to capture a few important booms in Asia. To assess the sensitivity of the results, a value of 1.96 is also used and does not change our main conclusions as discussed below.

\section{A. Identifying Credit Booms: An Example}

The case of Indonesia could serve as a useful illustration. The top panel of Figure $\mathbf{3}$ shows the logarithm of real credit and its trend, which is determined by using the detrending method popularized by Hodrick and Prescott (1997), the HP filter. As in Mendoza and Terrones (2008), the penalty parameter is set to 100, which is typical for annual data, and the filter is used over the entire sample, rather than creeping trends as used in Gourinchas and others (2001), for example. To the trend, 1.55 times the standard deviation of the cycle is added, yielding the threshold which determines the occurrence of a credit boom. Notice that the thresholds are also country-specific (in contrast to those used in Gourinchas and others, 2001), ensuring that credit booms are unusually large deviations relative to a country's typical credit cycle.

The lower panel of Figure 3 perhaps conveys the methodology more intuitively. It shows the deviation of real credit from trend-the cyclical component. In this case, because the cyclical component exceeds the cut-off threshold, identified by the dashed horizontal line and equal to 1.55 times the standard deviation of the cyclical component of real credit, a boom is identified. A lower threshold, uses one standard deviation, and is used to pin down the start and end dates. In sum, a credit boom occurred in Indonesia in the late 1990s, starting in 1996, ending in 1998, and with a peak in 1997.

While some studies use the credit-to-GDP ratio (Gourinchas and others, 2001; Barajas and others, 2011), this papers follows Mendoza and Terrones (2008) and uses real credit. This is because the credit-to-GDP ratio has at least two limitations. First, there can be situations when both nominal credit and GDP are falling and yet the ratio increases because GDP falls more rapidly, which could result in misleading conclusions. Second, the credit-to-GDP ratio does not allow for the possibility that credit and output could have different trends, which is important if countries are undergoing a process of financial deepening, or if for other reasons the trend of GDP and that of credit are progressing at different rates.

level data using the IMF's Corporate Vulnerability Utility. For credit, as discussed further below, IFS lines 22d and when available $42 \mathrm{~d}$ were used. After the credit series were adjust for structural breaks, they were deflated by end-of-period CPI to obtain the real credit series. 
It should also be noted that other than the baseline threshold parameter of 1.55 used in this paper, there are a few other departures from Mendoza and Terrones (2008). First, per capita measures are not used. Also, real credit is defined as the end-of-period stock of credit divided by the consumer price index (CPI), rather than the slightly more elaborate techniques (as used by used in Mendoza and Terrones, 2008, for example), which may lead to excess smoothing. ${ }^{5}$ A comparison of booms identified in this paper and those in Mendoza and Terrones (2008) verify that these departures are not critical.

\section{B. Focusing Only on Bank Credit Could Yield Misleading Policy Implications}

The choice of credit aggregate used is, however, a potentially important issue. Owing to data limitations, particularly due to short time series, the analysis here concentrates on bank credit to the private sector (IFS line 22d). Only in some cases (for example, the United States, Japan, Korea, and Singapore) could we complement the bank credit series with credit extended to the private sector by nondepository financial institutions (IFS line 42d). This is a crucial point because credit booms can arise owing to the availability of funds provided by nonbank institutions which may not be in the purview of regulatory and supervisory authorities.

Korea is a case in point. Figure 4 depicts the cyclical components of Korean real credit using a narrow (only bank credit, IFS line 22d) and a broader definition of credit (IFS line 22d plus the available IFS 42d lines). As shown in the figure, if only bank credit is used, the algorithm described above indicates the occurrence of a boom in 2002. However, once bank credit is complemented by credit extended by other institutions - through, for example, bank trust accounts - then a boom with a peak in 1998 on the eve of a sharp recession and period of financial distress is identified. As is clear from the figure, relying solely on credit extended by banks does not give off any early warning, and would deprive policymakers of a useful signal that could expedite corrective actions to foster financial stability. Therefore, the rapid rise in nonbank intermediation poses a challenge in detecting booms, implying that the perimeter of financial supervision should be widened to ensure vulnerabilities are detected early and contained.

\footnotetext{
5 These are used to correct for possible distortions caused by hyperinflationary episodes. However, when both methods were compared in the case of Argentina, for example, there were not any notable differences. In terms of other robustness checks, other values of the HP penalty parameters were also used, for example, 6.25 as suggested by Ravn and Uhlig (2002), but did not change the main conclusions of the papers. These additional results and robustness checks are available from the authors upon request.
} 


\section{WHAT Do CREDIT BOOMS LOOK LIKE?}

Using an event study, credit booms which were associated with crises are differentiated from booms that were not, which is in the spirit of Barajas and others (2011). Figure 5 shows the typical evolution of these booms over seven-year windows centered at their peaks. To mitigate the affect of outliers, median values are presented over the build-up (or pre-peak) phase ( $t-3$ to $t-1$ ), the peak (centered at year $t$ ), and the ending phase (or post-peak) phase $(t+1$ to $t+3) .{ }^{6}$ To provide further context, the 13 "worst" booms (the "terrible 13") which ended in financial crises and severe recessions are shown. ${ }^{7}$

While this paper will focus on real credit, nominal credit, and the credit-to-GDP ratio (all deviations from trend) are shown, and display similar dynamics during booms as shown in Figure 5. It is not surprising that the booms which ended abruptly were characterized by more excessive credit fluctuations in the pre-peak phase. More importantly, a protracted downward trajectory of credit continues for three years after the peak, especially for the 13 worst boom-bust episodes.

As shown in Table 1, of the 99 credit booms identified, 60 took place in emerging economies, of which 16 and 44 booms occurred in Asian and non-Asian emerging economies, respectively. In the last year of our sample, 2010, only one boom was identified for Hong Kong SAR. Concentrating on booms across emerging economies, certain features are worth highlighting:

- $\quad$ Duration. As shown in Figure 6, a typical boom lasts about three years, with a buildup, peak, and ending phase each lasting one year on average. There seems to be modest evidence that booms are asymmetric for emerging economies overall. However, in Asia, while the average build up phase slightly exceeds a year, the ending phase is much shorter. This indicates that booms in Asia are more asymmetric, and tend to end more abruptly relative to other emerging economies.

- $\quad$ Temporal distribution. While booms across emerging economies in the 1980 were more evenly distributed, those associated with the crises in the 1990s are bunched around 1997 as shown in Figure 7. More recently, and now conventional wisdom, there are quite a few booms clustered around 2007.

\footnotetext{
${ }^{6}$ In the case of Indonesia discussed above, for example, the peak was identified to have occurred in 1997, and so the boom will be centered around 1997 corresponding to year $t$.

${ }^{7}$ The thirteen most severe emerging economy boom-bust episodes are: Costa Rica, 1979; Chile, 1980; Argentina, 1982; Uruguay, 1981; the Philippines, 1983; Nigeria, 1987; Venezuela, 1988; Mexico, 1994; Bulgaria, 1996; Indonesia, 1997; Malaysia, 1997; Thailand, 1997; Korea, 1998. Each was characterized by an acute financial crisis and a severe recession, with real GDP growth contracting by 9 percent on average once the boom ended in a credit bust.
} 
- $\quad$ Capital inflows. Credit booms are tightly interconnected with episodes of large (net) capital inflows (Figure 8). These capital inflow episodes are based on Reinhart and Reinhart (2009) and consistent with earlier work by Cardarelli and others (2010). ${ }^{8}$ Asian booms in particular appear to have a higher likelihood of being preceded by an episode of large capital inflows in contrast to booms experienced by other emerging economies.

- $\quad$ Rapid credit growth, booms, and busts. An episode of rapid credit growth is identified when real credit growth exceeds a threshold of one times the cyclical standard deviation by contrast to the 1.55 value used to determined booms. Recall that the one standard deviation value was used to demarcate the beginning and ending phases of credit boom. As shown in Table 2, episodes of rapid credit growth have about a fifty-fifty chance of mutating into a boom. This is important, because historically, booms often ended abruptly in the form of crises (Table 3).

\section{When might credit growth be a concern?}

Rapid credit growth could be associated with brewing financial imbalances, eventually jeopardizing both financial and macroeconomic stability. Therefore, policymakers tend to focus on credit growth (rather than deviations from trend), because it is easier to monitor. Credit growth rates during booms may at first seem counterintuitive. Specifically, booms associated with crises actually yield lower median growth rates during the run-ups to their peaks as shown in Table 4. While these median growth rates were taken over the three year pre-peak phases, as highlighted in Figure 6, booms tend to last three years all together, with only one-year build-up phases. Therefore, because about half of the booms ended in busts with protracted credit downtrends, as shown in Figure 5, these episodes are pulling down the credit growth numbers. By contrast, for booms that not associated with crises, likely financial deepening was associated with persistent credit growth, thereby pushing up the medians reported in Table 4. Therefore, with the risk of oversimplification and ignoring countryspecific circumstances, real and nominal credit growth exceeding 15 and 20 percent, respectively, could warrant closer financial sector surveillance.

\section{The Dynamics of Credit Booms}

In this section, with the goal of uncovering warning signs that may help differentiate between booms that ended more smoothly versus those that ended in disruptive credit busts, selected macroeconomic, financial, corporate- and banking-sector indicators are analyzed, some of which are shown in Figure 9 through Figure 13. In what follows, it will be shown that credit booms are influenced by external factors (including capital inflows) and domestic factors (for example, monetary policy).

\footnotetext{
${ }^{8}$ Cardarelli and others (2010) is based on their previous studies which includes Cardarelli and others (2007).
} 


\section{A. External Factors}

In terms of external factors, credit booms seem tightly interconnected with episodes of large capital inflows. As shown in Figure 8, almost 60 percent of all emerging economy credit booms were preceded by an episode of large capital inflows. Figure 9 shows the pattern of net private capital inflows (as a percent of GDP) during the seven-year window centered on the peak of a typical credit boom. Booms ending smoothly, booms ending abruptly, and the 13 worst boom-bust episodes, registered net private capital inflows (as a percent of GDP), of about two, four, and six percent, respectively, during the pre-peak phase. Notice the sharp reversal of these flows, which in the case of the 13 worst boom-bust episodes, was over 10 percentage points.

\section{The composition of capital flows is important}

The composition of capital flows sheds light on these abrupt dynamics. In particular, booms which ended in credit busts were characterized by having large portfolio and other (bank) flows. While both portfolio and bank flows tend to have relatively short maturities, bank flows are especially precarious. The typically volatile nature of bank flows financing the large pre-peak current account deficits may have exacerbated the abrupt reversals of key external variables because these flows may have come to a "sudden stop" or even reversed (see for example, Calvo and others, 2004). In particular, notice the sharp reversal of the current account balance of about 10 percentage points in the 13 worst boom-bust episodes, which was effected through a combination of a real exchange rate depreciation of about 25 percent, and a contraction of domestic demand (discussed below).

\section{The limited role of international interest rates}

It is also worthy to note that international interest rates, measured using the Federal funds rate (and a proxy for global liquidity conditions), is virtually flat throughout the seven-year window, which is consistent with Gourinchas and others (2001). Furthermore, echoing Tornell and Westermann (2002), large exogenous shocks do not seem to trigger credit booms in emerging economies - this is true for the U.S. interest rate, but also for different measures of the terms of trade (not shown, but available from the authors upon request). Therefore, while credit booms tend to be preceded by episodes of large capital inflows, this seems to coincide with period during which international interest rates are fairly stable. ${ }^{9}$

\footnotetext{
${ }^{9}$ Along with many other studies, including those cited above, international interest rates (such as the Federal funds rate) was used as a proxy of global liquidity conditions. However, policy interest rates alone may not be able to accurately represent the level of global liquidity at all times, especially more recently. Intuitively, the international interest rate series could be complemented by other metrics, such as global money supply. While nonconventional monetary policies across some advanced economies likely affected global liquidity conditions, this is a more recent phenomenon and for future research.
} 


\section{Summary}

In sum, the large current account deficits in the build-up phase of a credit boom were associated with a surge in bank inflows, amid little movement in international interest rates. Once the booms peaked however, there was a sharp reversal across the key variables capturing external sector developments.

\section{B. Domestic Factors}

As with the external variables, in general, booms are followed by sharp reversals in key domestic macroeconomic variables as well. As shown in Figure 10, there is an upswing in real GDP, underpinned to a large degree by strong domestic demand as the credit boom builds, which is subsequently followed by an abrupt contraction. While real GDP tied to booms ending relatively smoothly hovered around potential, those that ended abruptly were above trend by about two to four percent in the pre-peak phase. Once the booms peaked, however, real GDP was four percent below trend for the 13 worst cases (and still on a downtrend even three years after the peak). This dynamic, in part, reflects the domestic counterpart of the sharp current account reversals discussed above-notice that real domestic demand can fall below trend by up to 8 percent. ${ }^{10}$

\section{Booms ending abruptly tend to be characterized by creditless recoveries}

Depressed economic activity is associated with booms which ended abruptly are related to the concept of "creditless recoveries" as introduced by Calvo and others (2006), and also discussed in Kannan (2010). In particular, Abiad and others (2011) argue that recoveries preceded by both a credit boom and banking crisis tend to be "creditless," and that the relatively weak macroeconomic performance during these creditless recoveries is likely the result of constrained growth due to impaired financial intermediation.

\section{Price stability may not ensure financial stability}

Note that credit booms do not appear to have a major effect on inflation. Reflecting the high degree of trade openness for many emerging economies, this suggests rising domestic demand imbalances are vented mainly through the current account and an appreciation of the exchange rate during the pre-peak phase. In terms of policy implications, therefore maintaining price stability (especially for countries that have adapted explicit or implicit inflation targets) does not seem to prevent the build-up of credit booms, echoing the insight

\footnotetext{
${ }^{10}$ It is useful to pause and discuss two caveats. First, as is clear from the figures presenting the results of the event study, credit booms could be associated with consumption and investment booms, for example. Second, the event study could have been conditioned on output rather than credit booms. Mendoza and Terrones (2008) discuss both issues in further detail, and for the latter, they find that while there is an output cycle associated with credit booms, there is no credit cycle associated with output booms.
} 
of Bean and others (2010). Note however, while modest, inflation does deviate from trend during the ending phase, which may reflect the pass-through of large devaluations or depreciations linked to currency crises.

\section{Low policy rates are associated with boom ending in abrupt credit busts}

In terms of macroeconomic policies, it seems that low policy rates appear to be associated with credit booms as shown in Figure 11. Both nominal policy and lending rates are below trend in the pre-peak phase. ${ }^{11}$ In particular, lower interest rates during the build-up phase are most prominent for the 13 worst boom-bust episodes. Lower policy rates bring down lending rates and the cost of borrowing more generally. In turn, this could fuel financial imbalances as it boosts asset price valuations and incentivizes risk taking and potentially excessive borrowing, which is elaborated in further detail below.

The appreciation of the nominal (effective) exchange is correlated with an increase in international reserves in the pre-peak phase. It could well be that policymakers are intervening in foreign exchange markets to stem the appreciation of the exchange rate, and thereby accumulate reserves. Honing in on the ending phase of credit booms, notice that for the 13 worst boom-bust episodes, there is a spike in policy rates, a sharp decline in reserves, but also a dramatic depreciation of the nominal (effective) exchange rate (of over 60 percent when measured from peak to trough). This dynamic is symptomatic of currency crises wherein an exchange rate peg comes under pressures. In turn, this triggers an initial defense of the heavily managed exchange rate regime through a drawdown in reserves and interest rates hikes. However, especially as reserves are depleted, eventually the fixed exchange rate regime is abandoned (Eichengreen and others, 1996). Of course the fallout from such credit busts is even worse when a twin (banking and currency) crisis unfolds (Kaminsky and Reinhart, 1999).

\section{Procyclical fiscal policy may have exacerbated downturns linked with credit busts}

Pre-peak fiscal policy stances also seem to have been loose and likely exacerbated the aftereffects of credit booms. Two measures of the fiscal policy stance are shown in Figure 11, and include the overall balance (government net lending-to-GDP ratio) and real government consumption (as a deviation from trend). While real government consumption is in line with its trend for the booms ending smoothly, it deviates markedly in the case of the booms which ended abruptly. Furthermore, taking both measures together, notice that fiscal policy seems to be largely procyclical, and thereby acts as an amplifier, rather than a dampener of business cycles, echoing the findings of Kaminsky and others (2005).

\footnotetext{
11 While not shown, the same is true for real policy and real lending rates, these results are available from authors upon request.
} 


\section{Summary}

In sum, looser macroeconomic policies appear to be associated with booms ending in disruptive credit busts. Furthermore, while generally too loose in the pre-peak phase, both monetary and fiscal policy stances may have been too tight once the credit boom peaked. These procyclical policy stances seem to have exacerbated the macroeconomic fluctuations associated with boom-bust episodes. Moreover, low policy rates have been associated with booms, while international interest rates are virtually flat during these periods.

\section{Credit booms are characterized by a deterioration of bank balance sheet soundness}

The focus now shifts to financial and banking-sector related variables during credit booms. Aggregate banking data is used to track the composition of bank assets and liabilities. To track the composition of the asset side of bank balance sheets, the bank credit-to-total assets ratio was used. Borio and Lowe (2004) have argued that this ratio can serve as an informative signal of the state of the financial cycle and thereby the vulnerability of the financial system to a shock to the economy. Further, Shin and Shin (2011) note that the ratio of total credit to money (M2) also serves such a role because when credit is increasing faster than money, the composition of the liabilities of the banking system is shifting away from deposit funding toward nondeposit (wholesale) funds to finance the growth in lending. To verify this assertion, the ratio of nondeposit liabilities to total liabilities is also included in the event study.

By tracking the composition of bank liabilities, it is possible to infer the state of the financial cycle. Specifically, during credit booms banks must raise funding in order to lend banks must raise funding in order to lend to their clients. The most important source of funding available to the banking sector is retail deposits of households. However, while retail deposits grow in line with household wealth, in a boom when credit is growing very rapidly, the pool of retail deposits is not sufficient to fund the increase in bank credit as discussed in Shin and Shin (2011). Other sources of funding must then be tapped to fund the increased bank lending. This is critical for open emerging economies because the rapid increases in non-core liabilities of the banking sector shows up as capital inflows through the increased foreign currency-denominated liabilities of the banking sector.

Turning back to the event study, Figure 12 indicates that the build-up phase of credit booms seem to be characterized by a deterioration of bank balance sheet soundness. The composition of the asset side of bank balance sheets aggressively shift toward credit extension, in part owing to looser lending standards as suggested by both the credit-to-M2 and the credit-to-asset ratios (for a theoretical framework, see for example, Dell'Ariccia and Marquez, 2006). At the same time, the quality of bank funding erodes as non-core (that is nondeposit) liabilities increase as a share of total liabilities—which seems especially relevant for the 13 worst boom-bust episodes. In part, the deterioration of bank balance sheet quality 
appears to be linked to a greater share of bank inflows, which typically have shorter maturities and likely denominated in foreign currency.

Furthermore, economies which have been experiencing relatively strong credit growth for a number of years raise concerns about the quality of this credit. Because of their lagging nature, this deterioration of credit quality tends to show up once the boom has busted in the form of substantially higher nonperforming loans. ${ }^{12}$ Bank profitability also seems relatively healthy in the pre-peak period, in part supported by buoyant (real) stock prices. However, notice that in the cases where the booms go bust, profitability tanks, as do stock prices, and nonperforming loans increase markedly (for a theoretical framework, see for example, Gertler and Kiyotaki, 2011).

\section{Corporate balance sheet health deteriorates during credit booms}

Tracking firm-level data during booms could usefully uncover key macro-financial linkages, and therefore several indicators that serve to gauge the health of the corporate sector are discussed below. A measure of leverage (the debt-to-equity ratio) is used to assess overall corporate sector vulnerability. Highly levered firms are more indebted, have less equity to support their assets and are thereby at higher risk of insolvency. The firm-level average interest rate (estimated by dividing interest expense on debt by total debt) is also included, and tends to be higher for firms that are more financially distressed. As a measure of profitability, return of equity (ROE) is included - firms may boost their ROE by taking on more leverage. To capture firm valuation, the standard price-earnings $(\mathrm{P} / \mathrm{E})$ ratio is used. To measure dependence of external finance (that is, external to the firm), the Rajan and Zingales (1998), RZ, index is used. It shows the percentage of total capital expenditures (CAPEX, which are broadly funds used to acquire fixed assets) that are externally financed.

The transmission of low policy rates would be the main source of the low firm-level average interest rates (Figure 13). This lower cost of capital is characterized by sharply increasing corporate leverage, particularly during the build-up phase in the booms the ended in credit busts. At the same time, lower pre-peak interest rates tend to artificially boost firm-level valuations, which are then reflected in buoyant stock prices. Return on equity is likely to have also been boosted by increased leverage as firms borrow to take advantage of lower average interest rates. The lower pre-peak interest rates incentivize excessive risk taking, borrowing, and investments in dubious investments (notice that the pattern of CAPEX resembles that of investment discussed above). Also notice that the RZ index is also much higher for the booms that ended abruptly. While firms may have had easy access to (possibly short-term foreign-currency denominated) funds during the pre-peak phase, once the boom goes bust, a creditless recovery may ensue where firms can only access internal sources of

\footnotetext{
${ }^{12}$ Bank-level data is based on the BankScope database, which while starting in the mid-1990s, has limited availability in the early years for many countries and time series.
} 
funds (for example, retained earnings), which would underpin weaker macroeconomic performance (Abiad and others, 2011).

Low policy rates inflate asset prices and thereby collateral values, and in turn, not only incentivize borrowing, but at the same time, (temporarily) increases borrowing capacity. Credit expands, and newly acquired debt is used to finance consumption and investment. In turn, buoyant activity raises asset prices thereby perpetuating this feedback mechanism and generating a virtuous cycle. However, this process is unsustainable, and when, for example, asset prices get depressed, this reverses the chain of events, bringing about a vicious cycle. These dynamics are consistent with the financial accelerator mechanisms developed by Kiyotaki and Moore (1997), Bernanke and others (1999), and Gertler and Kiyotaki (2010). More generally, there are many studies which discuss how financial intermediation (especially through balance sheets) can amplify and prolong the effects of real shocks, and are relevant to the results discussed above.

\section{Summary}

In sum, low policy rates seem to have, in part, exacerbated the deterioration of bank and corporate balance sheet health. Low policy rates bring down the cost of borrowing, implying lower firm-level average interest rates, thereby incentivizing excessive risk taking, borrowing, and looser lending standards, which seem to be related to the distinct increase in bank credit. These imbalances make the economy more vulnerable to shocks, and help explain the severe contractions that tend to be associated with credit boom-bust cycles.

\section{V.99 CREDIT BALLOONS}

This section of the paper makes use of the 99 credit booms identified across both advanced and emerging economies. As in Mendoza and Terrones (2008) it contrasts credit booms across these two country groups, but with several notable differences:

- $\quad$ First, this paper emphasizes the important of macroeconomic policies. In particular, the importance of monetary policy is highlighted. As discussed above, low policy rates may have contributed to the build-up of credit booms in emerging economies, but is this the case for advanced economies?

- $\quad$ Second, it extends there sample to include the global financial crisis which intensified with the Lehman Brothers bankruptcy. This allows the identification of several credit booms that were associated with the onset and severity of the global slowdown (for example, a boom is identified for the United States with a peak in 2007).

- $\quad$ Third, this paper considers a larger set of countries that may be useful in terms of drawing lessons. For example, booms are identified in Bulgaria and Estonia with peaks in 1996 and 1997, respectively, before the 1998 Russian crisis. A boom also 
occurs in the United Arab Emirates with a peak in 2008, which is associated with financial trouble linked to Dubai World.

- $\quad$ Fourth, a larger set of booms, 99, are analyzed here in contrast to the 49 analyzed by Mendoza and Terrones (2008) owing to the use of a lower threshold of 1.55 in contrast to 1.75. The main conclusions are also robust if the cutoff value is set to 1.96.

- $\quad$ Fifth, this paper is the first to investigate the type of inflows in the context of credit booms. For example, the role of portfolio and other (banks) flows is emphasized in particular. In addition, this paper also underscores the importance of monitoring the liability composition of bank balance sheets.

\section{A. Credit Booms Across Advanced and Emerging Economies}

Although the main takeaway of this section is that loose pre-peak monetary policy appears to be associated with the build-up of credit booms across both advanced and emerging economies, a puzzling finding is discussed first. Specifically, while most of the results are consistent with Mendoza and Terrones (2008), there is one important distinction which warrants further research and is shown in Figure 14. The real credit and inflation deviations from trend are large for emerging economies, but the opposite is true for GDP and the other main components of aggregate demand. In other words, this implies that business cycles are more volatile in advanced economies relative to emerging economies during credit booms. To help unravel this puzzling result, three hypotheses are tested. Focusing on real GDP, these hypotheses are formulated as follows: (i) Is it that the threshold of 1.55 introduces booms that generate spurious patterns owing to unique country-specific developments? (ii) Is it because Mendoza and Terrones (2008) use international prices (from the Penn World Tables, 6.2), while real GDP here is denominated in local currency units (from the IMF World Economic Outlook database)? (iii) Is it because of the booms which peaked around 2007, which involved advanced economies?

Figure 15 provides a first pass at trying to address these questions. Using a threshold of 1.96 (rather than 1.55) does not change the results much. However, using the same countries as in Mendoza and Terrones (2008) or using real GDP denominated in international prices helps, with the exception of period $t+3$. Could this then be because of the booms across advanced economies (including the United States) which peaked in 2007 and where followed by protracted slowdowns? Once again, except for the third year after the peak $(t+3)$, emerging markets seem to have more volatile business cycle fluctuations in contrast to advanced economies, a results which could be investigated further.

\section{Emerging economy current account deficits are financed with less stable inflows}

Variables capturing external sector developments are more volatile for emerging economies. The results pertaining to the current account, capital flows, and the real exchange rate are in line with other studies. In the context of credit booms, however, Figure 16 shows that while 
advance economy current account deficits tend to be financed by portfolio flows, those in emerging economies are funded primarily by non-FDI flows, and in particular, as emphasized above, other (bank) flows. This more fickle source of current account financing is surely to be an important factor behind the more drastic reversals in emerging economy external balances during boom-bust cycles.

\section{Loose pre-peak monetary policy is associated with the built-up of credit booms}

Turning to macroeconomic policies, Figure 17 indicates that emerging economies tend to be characterized by more procyclical monetary and fiscal policy stances. This is more apparent in the context of fiscal policy as captured by the cyclical dynamics of real government consumption, but also by the evolution of the overall fiscal balance, and consistent with the findings of Kaminsky and others (2005). Pre-peak monetary policy seems loose across both country groupings, but slightly more expansionary in the context of emerging economies. It seems that the potential link between loose monetary policy and credit booms is not just an emerging market phenomenon. In fact, there are arguments that the Federal funds rate was too low (when compared to a simple Taylor-type interest rate rule), and therefore caused the credit/house price boom in the United States in the run-up to the Lehman Brothers bankruptcy (Taylor, 2010).

\section{Effects of loose monetary policy weakens bank- and corporate-sector balance sheets}

Financial and banking sector variables are also generally more volatile in emerging economies. Note the non-core (nondeposit) liabilities-to-total liabilities and the foreign liabilities-to-total liabilities ratios shown in Figure 18. While the former spikes right before the peak, the latter peaks a few years before the credit boom starts to unwind across emerging economies. This could be that initially banks fund credit expansion using foreign currency denominated bank flows, but then switch to other sources of wholesale funding, or start using off balance sheet vehicles. In terms of asset prices, both real house and stock prices seem more volatile for advanced economies. House price dynamics are broadly consistent with Mendoza and Terrones (2008). However, note because of data limitations pertaining to a larger set of booms across countries that do not produce such time series (for example, there is not a property/house price index for India), this result should be interpreted with some caution. As for real stock prices, as in the case of real GDP above, it might be because of the booms in advanced economies which peaked in 2007 as well as a larger set of booms used, which include countries that just recently established stock exchanges.

The effects of loose monetary policy are especially noticeable when corporate sector data is analyzed. While the patterns of real and nominal policy rates were close across both country groupings, as shown in Figure 19, the average interest rate in emerging economies is much

lower than that of advanced economies during the pre-peak phase. These lower interest rates make borrowing and risk taking more attractive, and are accordingly associated with higher leverage ratios, more CAPEX, and a greater dependence on external financing. 


\section{Summary}

In sum, loose pre-peak monetary policy appears to be associated with the build-up of credit booms across both advanced and emerging economies. This is especially striking when firmlevel data is analyzed and serves to highlight the potentially pivotal role of monetary policy in driving credit dynamics across both country groupings.

\section{CONCLUSION}

Since 2009, credit growth has been elevated across many emerging economies. This may be a concern because episodes of rapid credit growth, especially credit booms, are typically associated with growing financial imbalances, which tend to end abruptly, typically in the form of financial crisis (especially in emerging Asia).

Focusing on 99 credit booms, 60 of which originated in emerging economies, this paper presents the findings of a comprehensive event study. Two main finding of most interest to policymakers are as follows:

- $\quad$ Loose macroeconomic policy stances seem to have contributed to the build-up of credit booms. In particular, domestic policy rates were low during the pre-peak phase of credit booms and likely fuelled macroeconomic and financial imbalances. For example, as credit booms build, they are jointly associated with growing bank and corporate balance sheet vulnerabilities and symptoms of overheating including: buoyant asset prices, strong domestic demand, widening current account deficits, and large capital inflows.

- In fact, while credit booms are associated with episodes of large capital inflows, international interest rates (a proxy for global liquidity) are virtually flat during these periods. Therefore, although external factors such as global liquidity conditions matter, and possibly increasingly so over time, domestic factors - especially monetary policy - also appear to be important drivers of real credit growth across emerging economies including those in Asia.

The main intention of this paper was to present key stylized facts that would inform policymakers, but also motivate future research. In particular, structural models could usefully refine and quantify some of the results presented here, could shed light on causal relationships, and conduct insightful counterfactual scenarios to better inform policymaking. 
Table 1. Credit Booms, Capital Inflows, and Crises

\begin{tabular}{|c|c|c|c|c|c|c|c|}
\hline & \multirow[b]{2}{*}{ Economy } & \multirow[b]{2}{*}{ Year } & \multirow[b]{2}{*}{ Threshold: 1.96} & \multirow[b]{2}{*}{ Capital inflow episode } & \multicolumn{3}{|l|}{ Crises: } \\
\hline & & & & & Banking & Currency & Any \\
\hline 1 & HKG & 1989 & 1 & . & . & . & . \\
\hline 2 & HKG & 1997 & - & 1 & - & . & . \\
\hline 3 & HKG & 2010 & 1 & & - & - & - \\
\hline 4 & KOR & 1998 & 1 & 1 & 1 & 1 & 1 \\
\hline 5 & SGP & 1983 & 1 & 1 & 1 & - & 1 \\
\hline 6 & SGP & 1998 & - & . & - & 1 & 1 \\
\hline 7 & TWN & 1994 & - & & 1 & 1 & 1 \\
\hline 8 & IDN & 1997 & 1 & 1 & 1 & 1 & 1 \\
\hline 9 & MYS & 1985 & - & 1 & 1 & - & 1 \\
\hline 10 & MYS & 1997 & 1 & 1 & 1 & 1 & 1 \\
\hline 11 & PHL & 1983 & 1 & 1 & 1 & 1 & 1 \\
\hline 12 & PHL & 1997 & 1 & 1 & 1 & 1 & 1 \\
\hline 13 & THA & 1997 & 1 & 1 & 1 & 1 & 1 \\
\hline 14 & CHN & 1992 & . & 1 & 1 & 1 & 1 \\
\hline 15 & IND & 1989 & . & 1 & 1 & 1 & 1 \\
\hline 16 & IND & 2007 & . & . & . & . & . \\
\hline 17 & TUR & 1997 & 1 & . & 1 & 1 & 1 \\
\hline 18 & ZAF & 1984 & . & 1 & . & 1 & 1 \\
\hline 19 & ZAF & 2007 & 1 & 1 & . & 1 & 1 \\
\hline 20 & ARG & 1982 & . & 1 & 1 & 1 & 1 \\
\hline 21 & BRA & 1985 & . & 1 & 1 & 1 & 1 \\
\hline 22 & BRA & 1993 & 1 & . & 1 & 1 & 1 \\
\hline 23 & $\mathrm{CHL}$ & 1980 & . & 1 & 1 & 1 & 1 \\
\hline 24 & $\mathrm{COL}$ & 1997 & 1 & 1 & 1 & 1 & 1 \\
\hline 25 & CRI & 1979 & 1 & & 1 & . & 1 \\
\hline 26 & ECU & 1982 & . & 1 & 1 & 1 & 1 \\
\hline 27 & MEX & 1994 & 1 & 1 & 1 & 1 & 1 \\
\hline 28 & PER & 1998 & . & & 1 & 1 & 1 \\
\hline 29 & URY & 1981 & . & 1 & 1 & 1 & 1 \\
\hline 30 & URY & 2002 & 1 & 1 & 1 & 1 & 1 \\
\hline 31 & VEN & 1988 & . & 1 & . & 1 & 1 \\
\hline 32 & VEN & 2007 & 1 & . & . & 1 & 1 \\
\hline 33 & ISR & 1979 & 1 & & . & . & . \\
\hline 34 & ISR & 1984 & 1 & 1 & . & . & . \\
\hline 35 & JOR & 1969 & 1 & & . & . & . \\
\hline 36 & EGY & 1981 & 1 & 1 & 1 & 1 & 1 \\
\hline 37 & PAK & 1986 & . & . & . & . & . \\
\hline 38 & PAK & 2007 & . & 1 & . & . & . \\
\hline 39 & $\mathrm{DZA}$ & 2002 & 1 & . & . & . & . \\
\hline 40 & CIV & 1977 & 1 & & . & . & . \\
\hline
\end{tabular}


Continued

\begin{tabular}{|c|c|c|c|c|c|c|c|}
\hline & \multirow[b]{2}{*}{ Economy } & \multirow[b]{2}{*}{ Year } & \multirow[b]{2}{*}{ Threshold: 1.96} & \multirow[b]{2}{*}{ Capital inflow episode } & \multicolumn{3}{|l|}{ Crises: } \\
\hline & & & & & Banking & Currency & Any \\
\hline 41 & MAR & 1976 & - & & - & - & - \\
\hline 42 & NGA & 1987 & - & 1 & - & 1 & 1 \\
\hline 43 & NGA & 2008 & 1 & & - & - & - \\
\hline 44 & BHR & 1976 & 1 & & - & - & - \\
\hline 45 & BHR & 2008 & 1 & - & - & - & - \\
\hline 46 & KWT & 1979 & - & & - & - & - \\
\hline 47 & KWT & 1997 & - & 1 & - & - & - \\
\hline 48 & LBN & 1984 & - & 1 & - & - & - \\
\hline 49 & OMN & 1998 & - & 1 & - & - & - \\
\hline 50 & QAT & 1993 & 1 & & - & - & - \\
\hline 51 & SAU & 1980 & 1 & - & - & - & - \\
\hline 52 & ARE & 2008 & 1 & & - & - & . \\
\hline 53 & LKA & 1979 & . & 1 & . & 1 & 1 \\
\hline 54 & LKA & 2006 & . & . & . & . & . \\
\hline 55 & TUN & 1989 & - & . & 1 & - & 1 \\
\hline 56 & TUN & 2001 & 1 & . & . & - & . \\
\hline 57 & BGR & 1996 & 1 & 1 & . & - & - \\
\hline 58 & EST & 1997 & . & . & . & . & . \\
\hline 59 & EST & 2007 & . & 1 & . & - & . \\
\hline 60 & SVN & 2006 & 1 & 1 & . & - & . \\
\hline 61 & JPN & 1972 & 1 & & . & - & . \\
\hline 62 & JPN & 1990 & . & . & 1 & . & 1 \\
\hline 63 & AUS & 1989 & . & 1 & 1 & . & 1 \\
\hline 64 & AUS & 2007 & . & 1 & . & 1 & 1 \\
\hline 65 & NZL & 1988 & 1 & 1 & 1 & . & 1 \\
\hline 66 & USA & 1999 & 1 & & . & - & . \\
\hline 67 & USA & 2007 & . & 1 & 1 & - & 1 \\
\hline 68 & GBR & 1973 & 1 & & 1 & 1 & 1 \\
\hline 69 & GBR & 1989 & 1 & 1 & 1 & 1 & 1 \\
\hline 70 & AUT & 1972 & . & & . & - & . \\
\hline 71 & AUT & 1979 & . & . & . & - & . \\
\hline 72 & AUT & 1991 & . & . & . & . & . \\
\hline 73 & BEL & 1979 & . & 1 & 1 & . & 1 \\
\hline 74 & BEL & 1989 & . & . & . & - & - \\
\hline 75 & BEL & 2007 & - & . & 1 & - & 1 \\
\hline 76 & DNK & 1987 & 1 & 1 & 1 & - & 1 \\
\hline 77 & FRA & 1990 & 1 & 1 & 1 & - & 1 \\
\hline 78 & FRA & 2007 & . & . & 1 & . & 1 \\
\hline 79 & DEU & 1972 & - & & . & - & - \\
\hline 80 & DEU & 2000 & . & 1 & . & . & . \\
\hline
\end{tabular}




\begin{tabular}{|c|c|c|c|c|c|c|c|}
\hline & \multirow[b]{2}{*}{ Economy } & \multirow[b]{2}{*}{ Year } & \multirow[b]{2}{*}{ Threshold: 1.96} & \multirow[b]{2}{*}{ Capital inflow episode } & \multicolumn{3}{|l|}{ Crises: } \\
\hline & & & & & Banking & Currency & Any \\
\hline 81 & ITA & 1973 & 1 & & - & 1 & 1 \\
\hline 82 & ITA & 1992 & 1 & 1 & 1 & 1 & 1 \\
\hline 83 & NLD & 1979 & 1 & & - & - & . \\
\hline 84 & NOR & 1987 & 1 & 1 & 1 & 1 & 1 \\
\hline 85 & SWE & 1990 & 1 & 1 & 1 & 1 & 1 \\
\hline 86 & CHE & 1970 & $\cdot$ & & - & - & - \\
\hline 87 & CHE & 1989 & 1 & & - & - & - \\
\hline 88 & CHE & 2007 & - & & 1 & - & 1 \\
\hline 89 & CAN & 1966 & $\cdot$ & & - & - & - \\
\hline 90 & CAN & 1979 & 1 & - & 1 & - & 1 \\
\hline 91 & FIN & 1990 & 1 & - & 1 & 1 & 1 \\
\hline 92 & GRC & 1972 & - & & - & 1 & 1 \\
\hline 93 & GRC & 2007 & . & 1 & 1 & . & 1 \\
\hline 94 & IRL & 1972 & $\cdot$ & & . & 1 & 1 \\
\hline 95 & IRL & 2006 &. & & 1 & . & 1 \\
\hline 96 & PRT & 1973 & 1 & & . & 1 & 1 \\
\hline 97 & PRT & 2000 & 1 & 1 & . & . & . \\
\hline 98 & ESP & 1991 & . & . & . & . & . \\
\hline 99 & ESP & 2007 & - & 1 & 1 & - & 1 \\
\hline
\end{tabular}

Note: Booms are indicated with country codes and years. Threshold 1.96 take a value of unity if the boom exceeded the more stringent threshold of 1.96 discussed in the main text. Capital inflow episodes take a value of unity if a credit boom was preceded by an episode of large capital inflows as based on Reinhart and Reinhart (2009). Crises takes a value of unity if a boom was associated with either a banking, currency, or another type of crisis as based on Reinhart and Rogoff (2009).

Source: Authors’ calculations. 
Table 2. Rapid Credit Growth and Booms

Episodes of Rapid Credit Growth which Morphed into Booms (in percent)

\begin{tabular}{cccc}
\hline Threshold & $\begin{array}{c}\text { Asian Emerging } \\
\text { Markets }\end{array}$ & $\begin{array}{c}\text { O ther Emerging } \\
\text { Markets }\end{array}$ & $\begin{array}{c}\text { All Emerging } \\
\text { Markets }\end{array}$ \\
\hline 1.55 & 55.2 & 47.8 & 49.6 \\
1.96 & 31.0 & 23.9 & 25.6 \\
\hline
\end{tabular}

Number of Rapid Credit Growth Episodes and Booms

\begin{tabular}{cccc}
\hline Threshold & $\begin{array}{c}\text { Asian Emerging } \\
\text { Markets }\end{array}$ & $\begin{array}{c}\text { 0 ther Emerging } \\
\text { Markets }\end{array}$ & $\begin{array}{c}\text { All Em erging } \\
\text { Markets }\end{array}$ \\
\hline 1.00 & 29 & 92 & 121 \\
1.55 & 16 & 44 & 60 \\
1.96 & 9 & 22 & 31 \\
\hline
\end{tabular}

Source: authors' calculations.

Table 3. Credit Booms Associated with Crises

\begin{tabular}{lrrrr} 
& Credit Booms & Banking Crises & Currency Crises & Any Crises \\
\hline Asian Emerging Markets & 16 & 11 & 10 & 12 \\
Other Emerging Markets & 44 & 14 & 18 & 20 \\
\hline All Emerging Markets & 60 & 25 & 28 & 32 \\
\hline
\end{tabular}

Source: authors' calculations.

Table 4. Pre-Peak Credit Growth

Booms Ending Smoothly (in percent)

\begin{tabular}{lccc}
\hline & $\begin{array}{c}\text { Nom inalcredit } \\
\text { growth }\end{array}$ & $\begin{array}{c}\text { Realcredit } \\
\text { growth }\end{array}$ & $\begin{array}{c}\text { Credit-to-G D P } \\
\text { Grow th }\end{array}$ \\
\hline Asian EMs & 26.2 & 20.0 & 6.3 \\
O therEMs & 31.8 & 16.0 & 11.1 \\
All E Ms & 30.3 & 18.0 & 10.1 \\
\hline
\end{tabular}

Booms Ending Abruptly (in percent)

\begin{tabular}{lccc}
\hline & $\begin{array}{c}\text { Nom inal credit } \\
\text { growth }\end{array}$ & $\begin{array}{c}\text { Realcredit } \\
\text { grow th }\end{array}$ & $\begin{array}{c}\text { Credit-to-G D P } \\
\text { Grow th }\end{array}$ \\
\hline Asian EMs & 20.2 & 15.6 & 6.7 \\
O therEMs & 31.7 & 15.2 & 7.6 \\
All EMs & 22.3 & 16.2 & 7.2 \\
\hline
\end{tabular}

Sources: au thors'calcula tions. 
Figure 1. Nominal Credit to Private Sector (Year-over-year percent change)

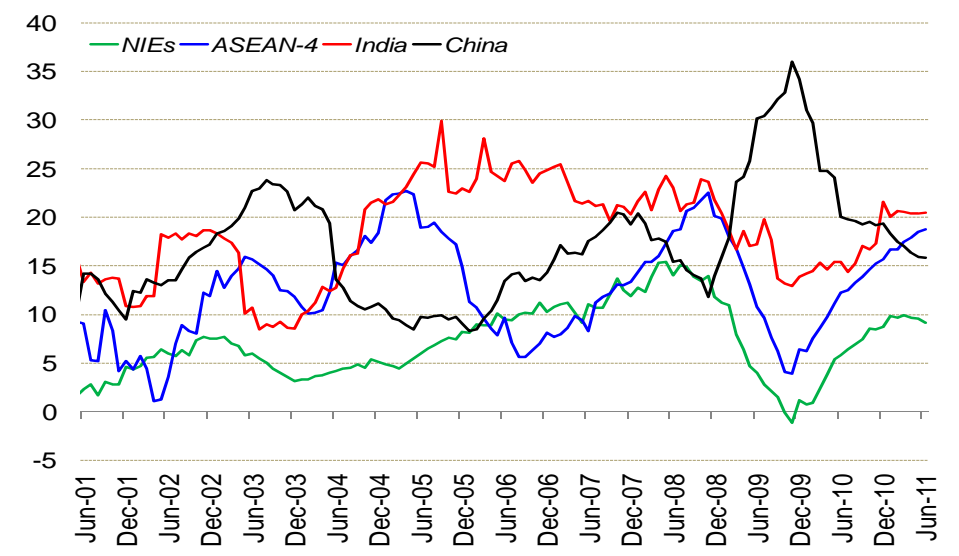

Sources: CEIC; Haver Analytics; and Authors' calculations.

Figure 2. Crises Associated with Emerging Market Credit Booms (In percent of respective booms)

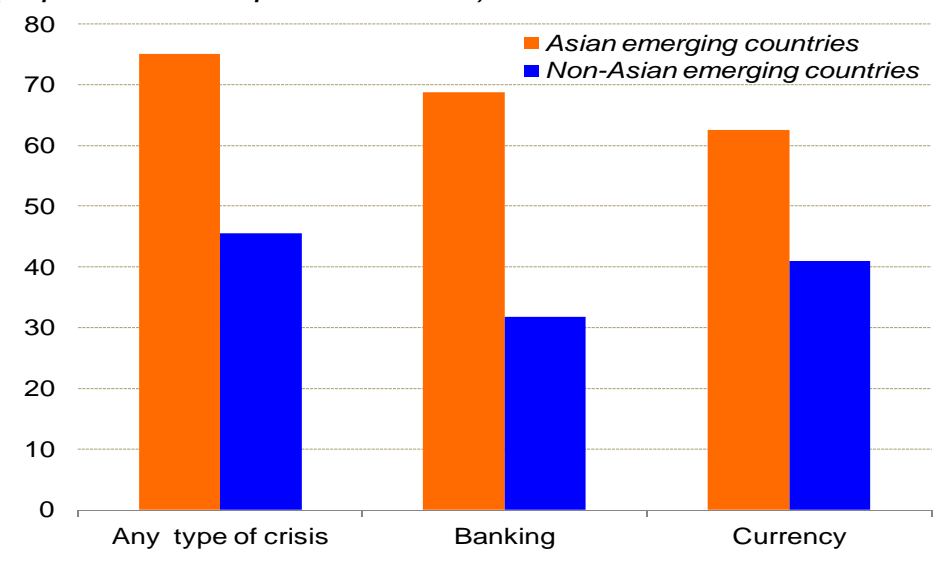

Source: Authors' calculations. 
Figure 3. Indonesia: Identifying Credit Booms (Percent deviation of log real credit from trend)
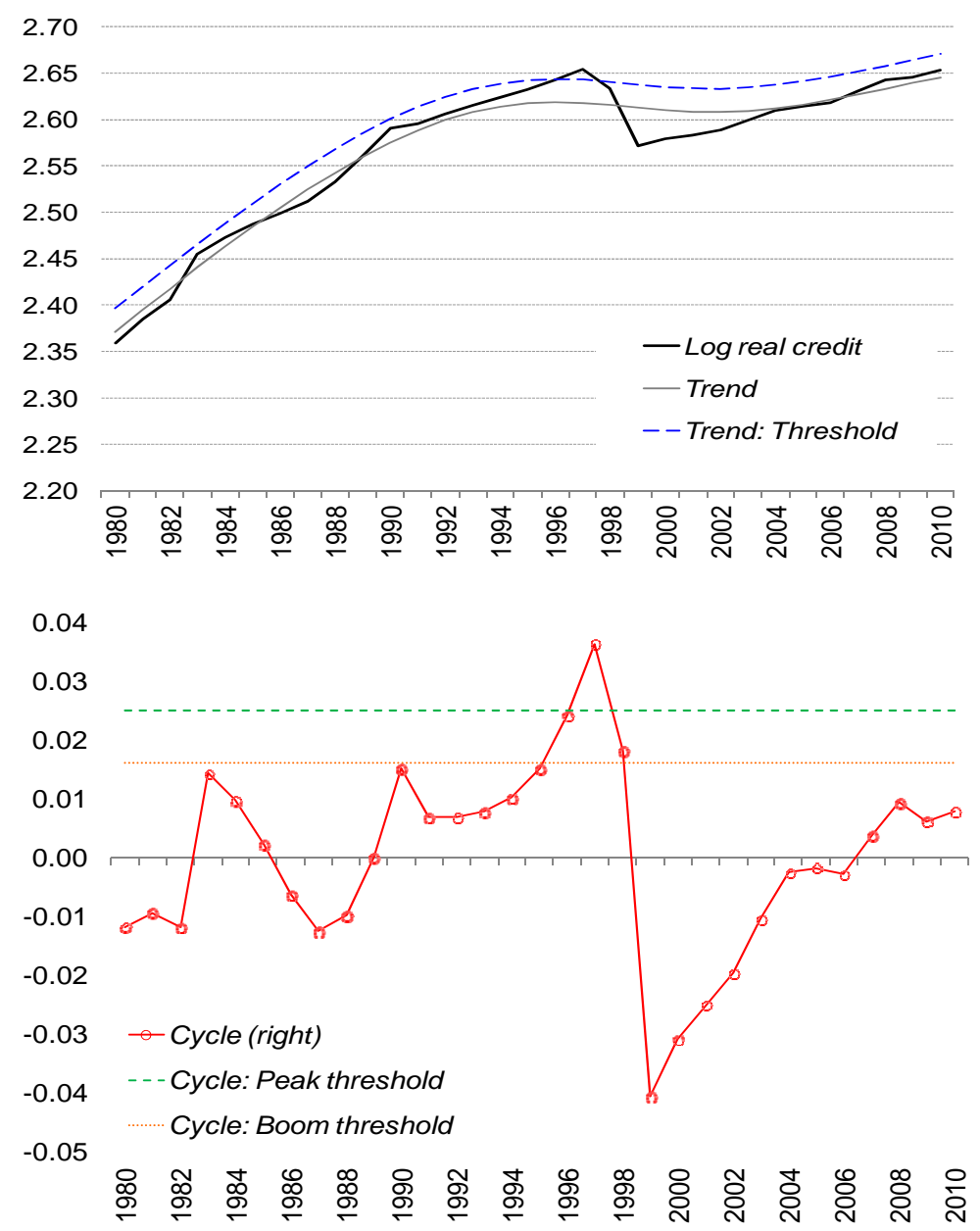

Source: Authors' calculations.

Figure 4. Korea: Identifying Credit Booms (Percent deviation of log real credit from trend)

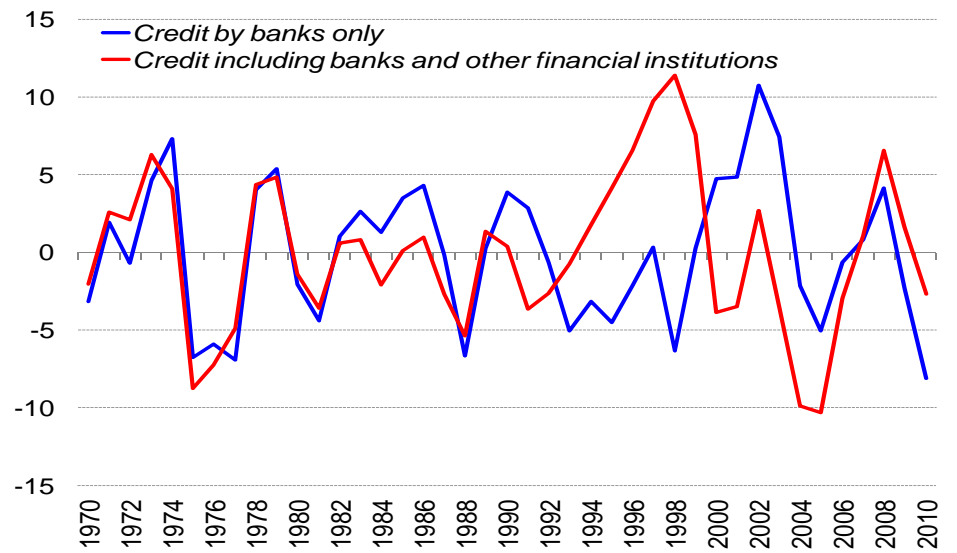

Source: Authors' calculations. 
Figure 5. Credit Dynamics During Booms

Real Credit

(In percent, deviation from trend)

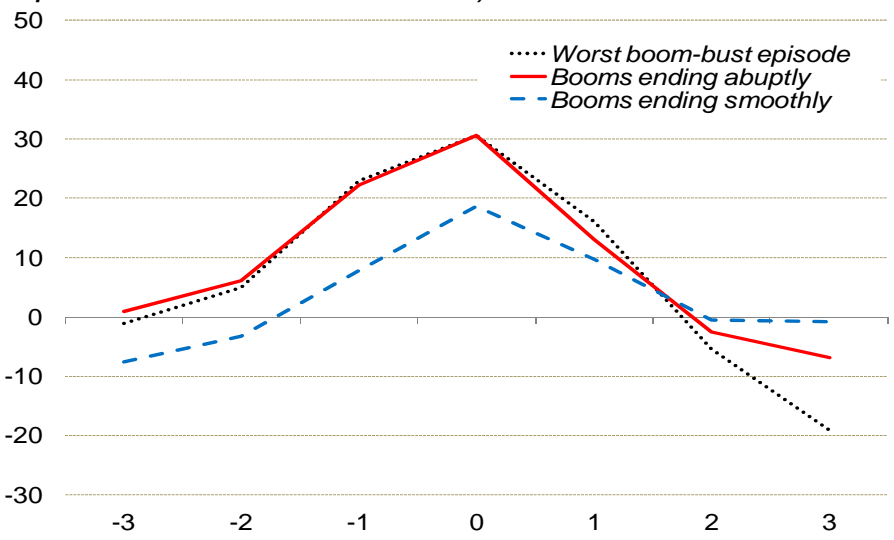

Nominal Credit

(In percent, deviation from trend)

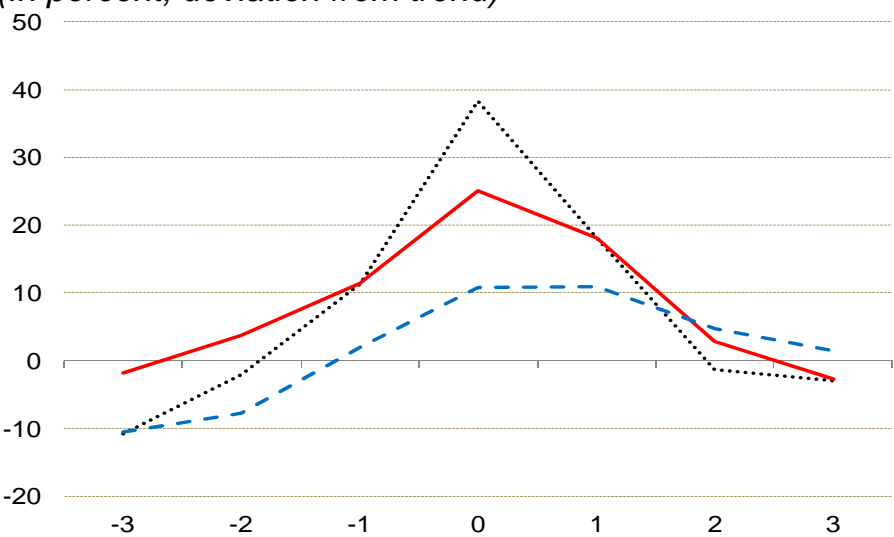

\section{Nominal Credit}

(In percent of GDP, deviation from trend)

$$
16
$$

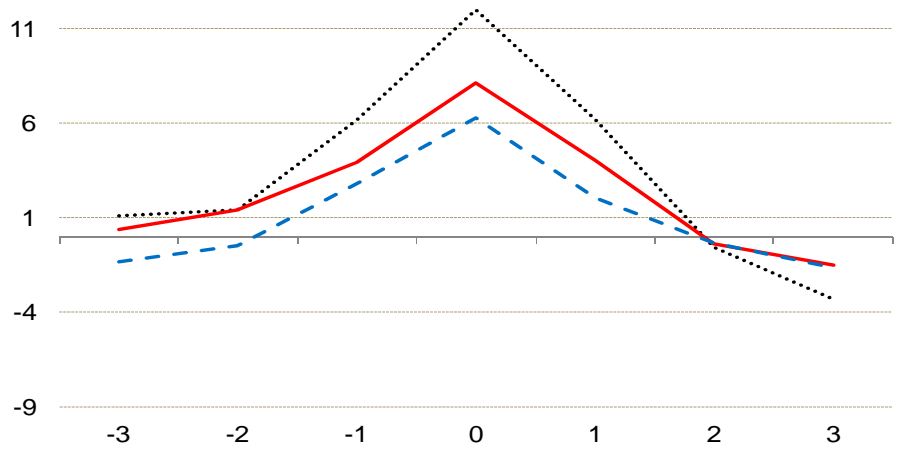

Source: Authors' calculations. 
Figure 6. Credit Booms: Duration

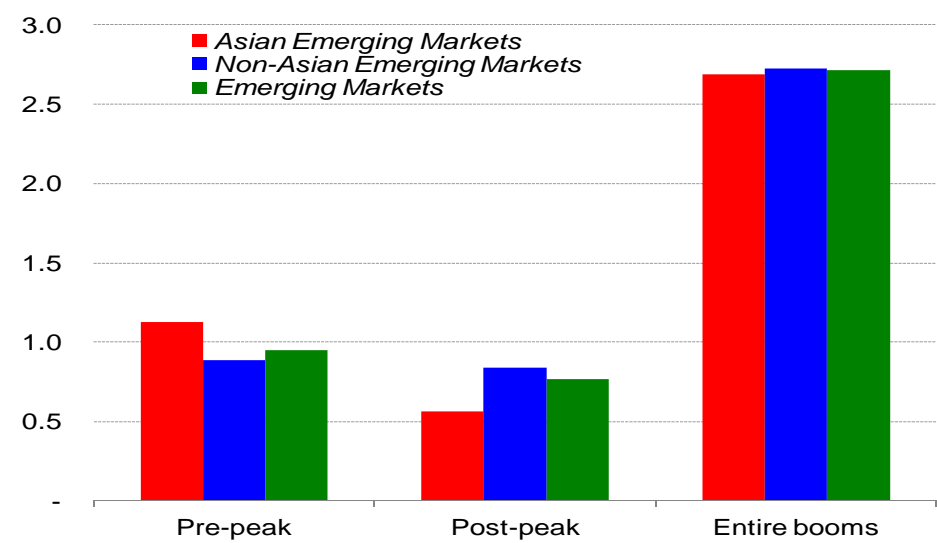

Source: Authors' calculations.

Figure 7. Peaks of Credit Booms Over Time

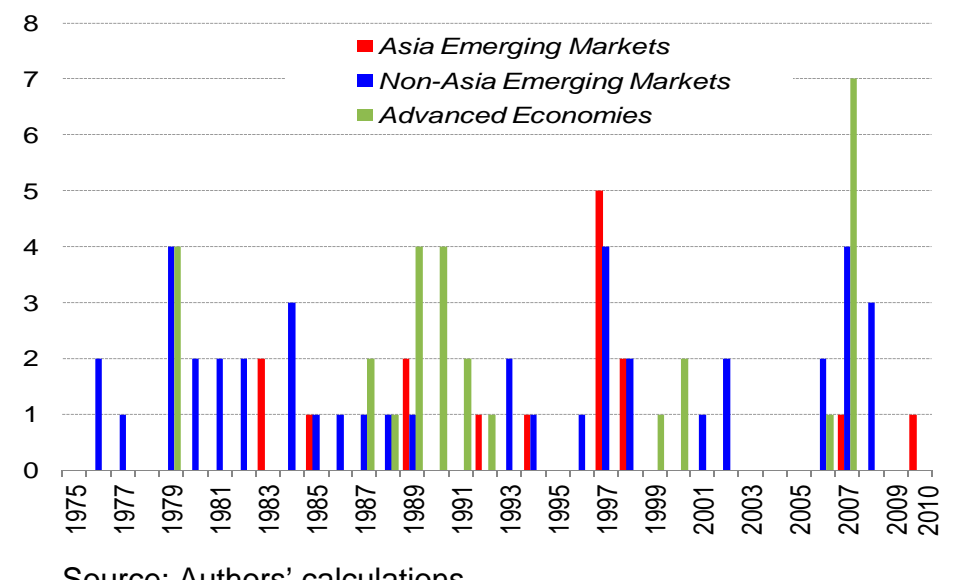

Source: Authors' calculations.

Figure 8. Credit Booms in Emerging Economies Associated with Episodes of Large Capital Inflows

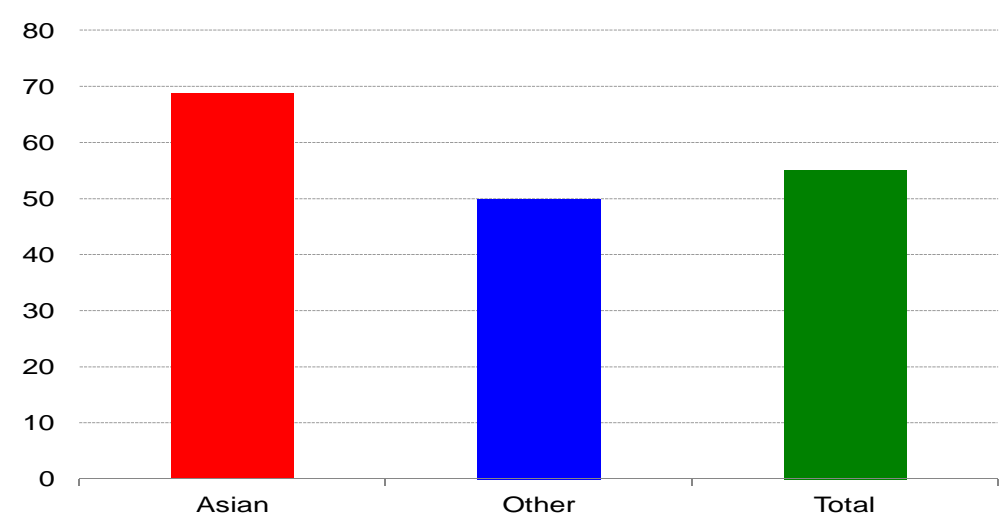

Source: Authors' calculations. 
Figure 9. Credit Booms: External Sector

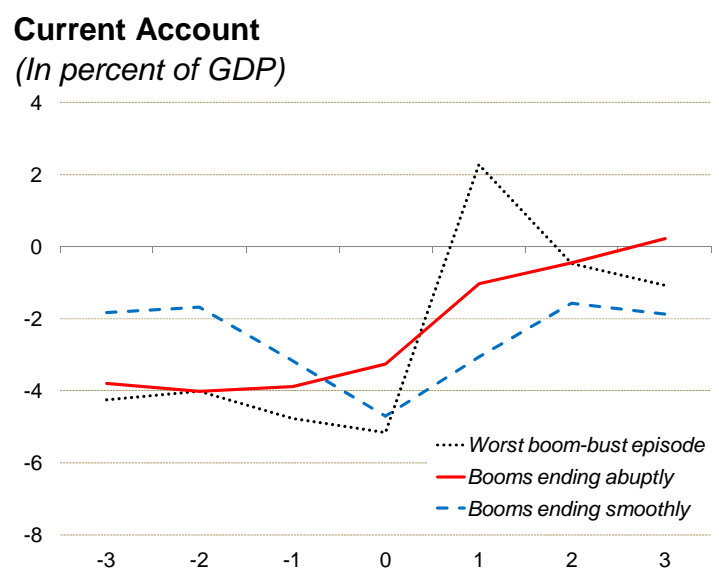

\section{Capital Flows}

(In percent of GDP)

Other flows

(In percent of GDP)

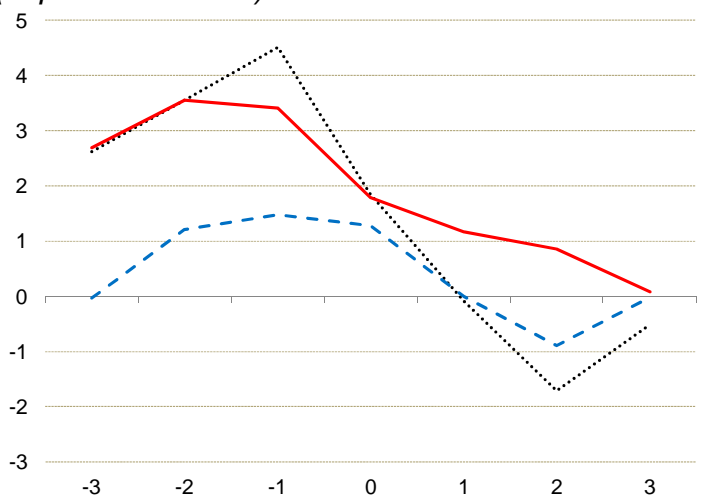

\section{Fed Funds Rate}

(Percentage points)

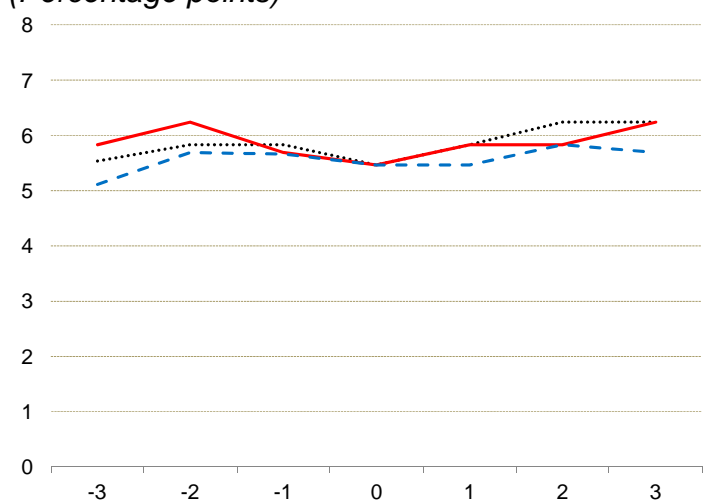

(In percent, deviation from trend)

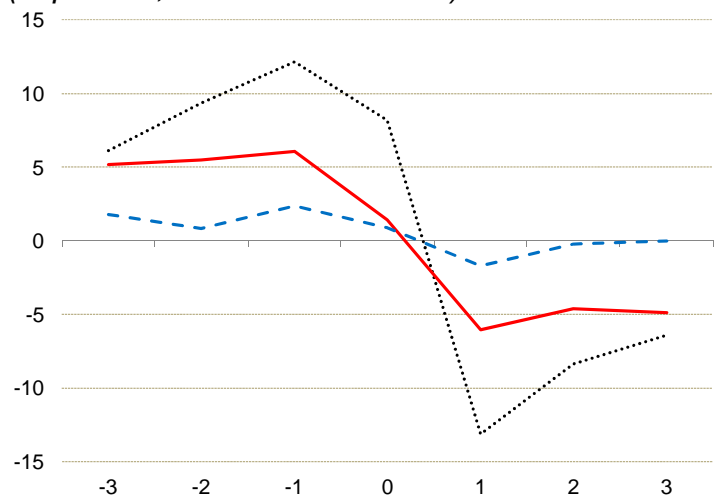

Sources: IMF WEO database; and authors' calculations. 
Figure 10. Credit Booms: Real Sector

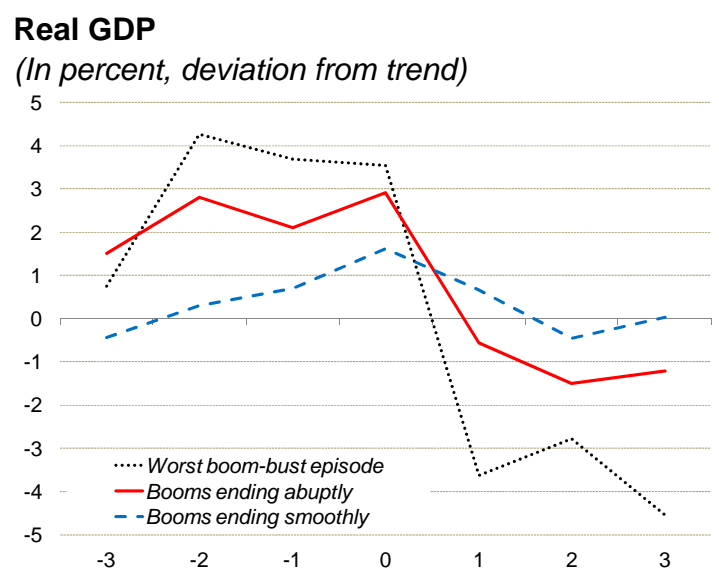

\section{Real Consumption}

(In percent, deviation from trend)

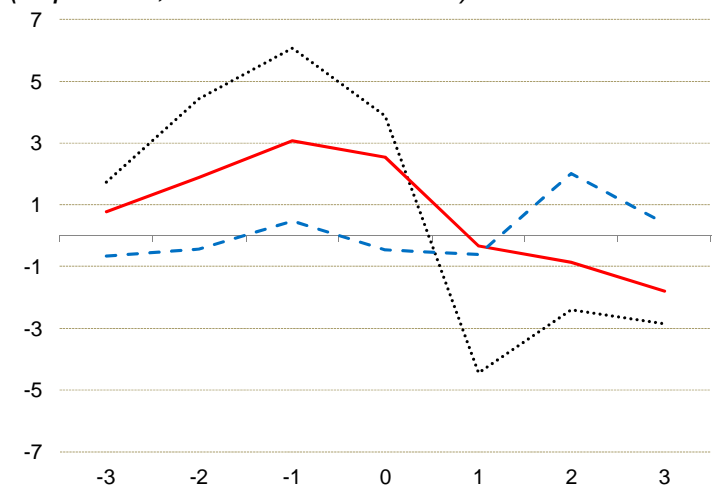

Real Domestic Demand

(In percent, deviation from trend)

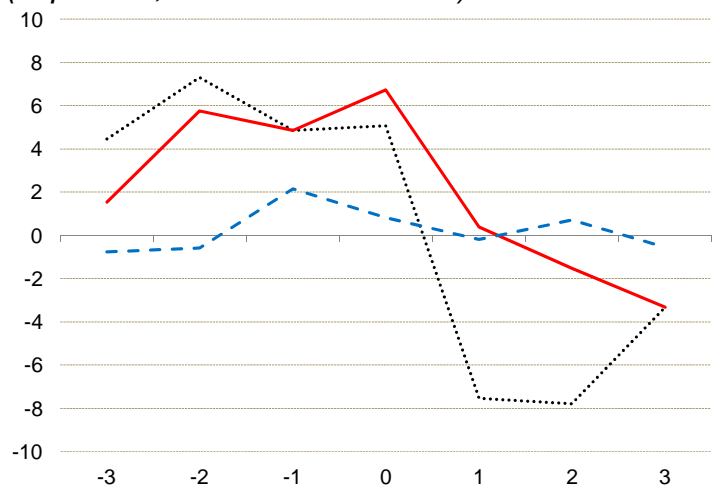

Real Investment

(In percent, deviation from trend)

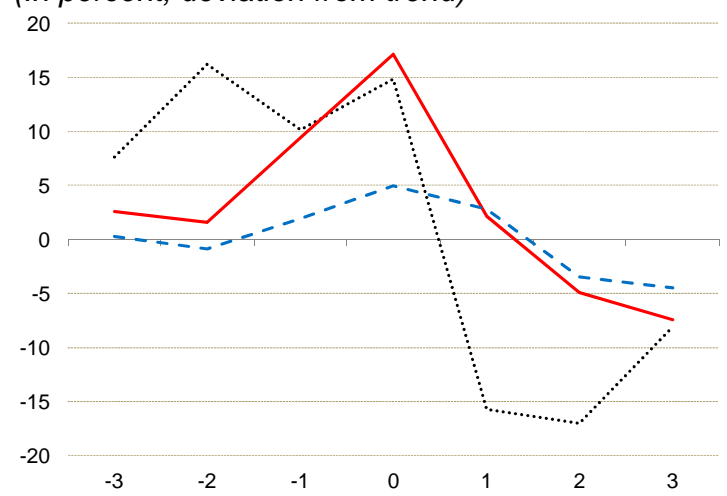

\section{CPI Inflation}

(In percent, deviation from trend)

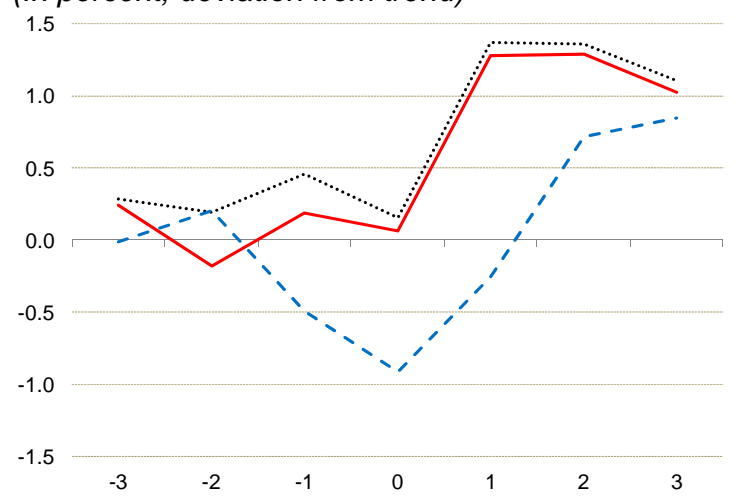

Real Absorption

(In percent, deviation from trend)

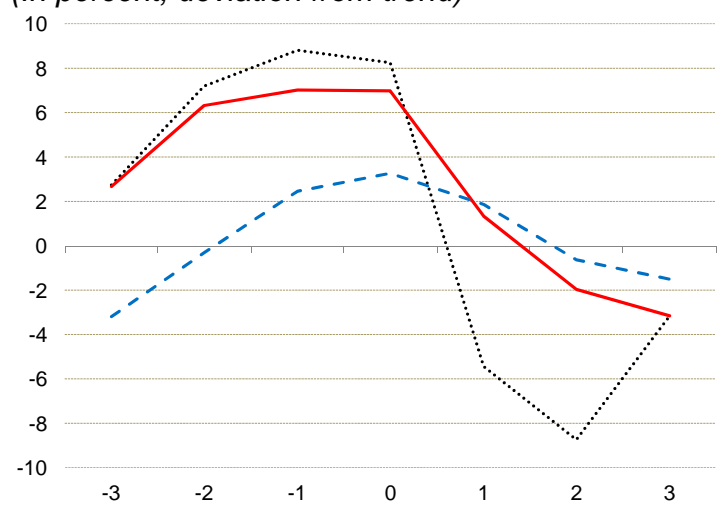

Sources: IMF WEO database; and authors' calculations. 
Figure 11. Credit Booms: The Role of Policies
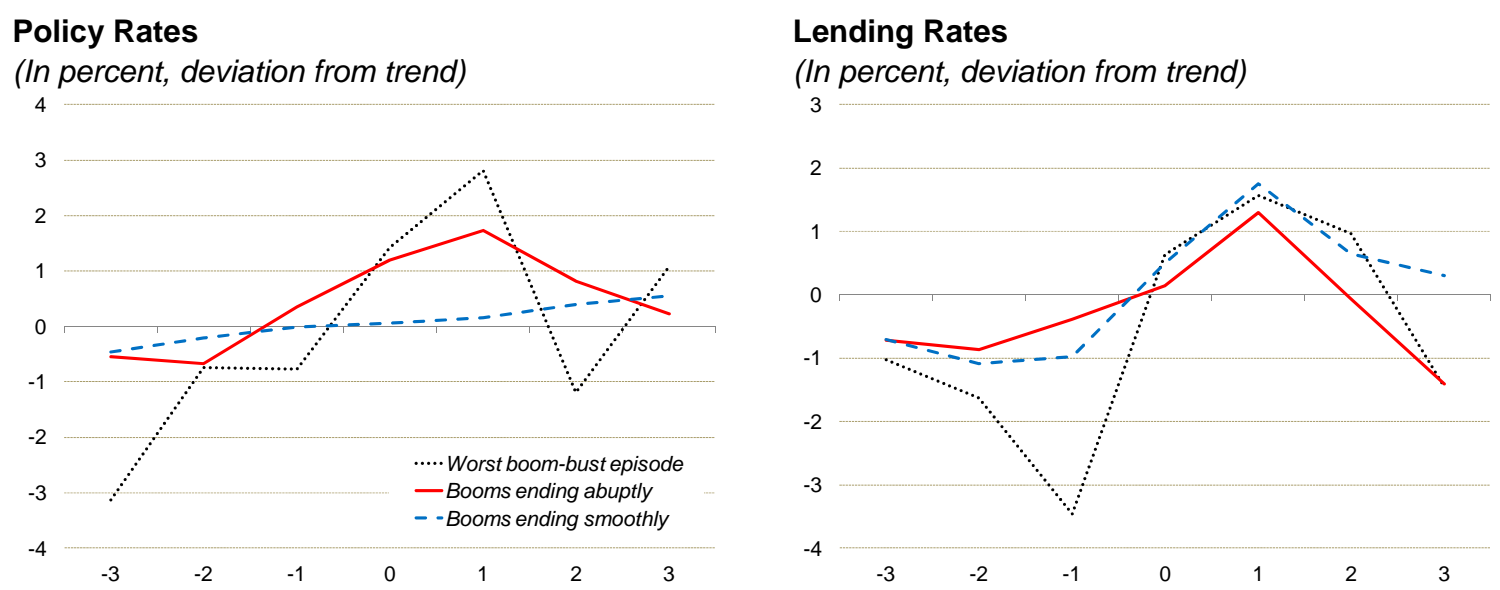

\section{NEER}

(In percent, deviation from trend)

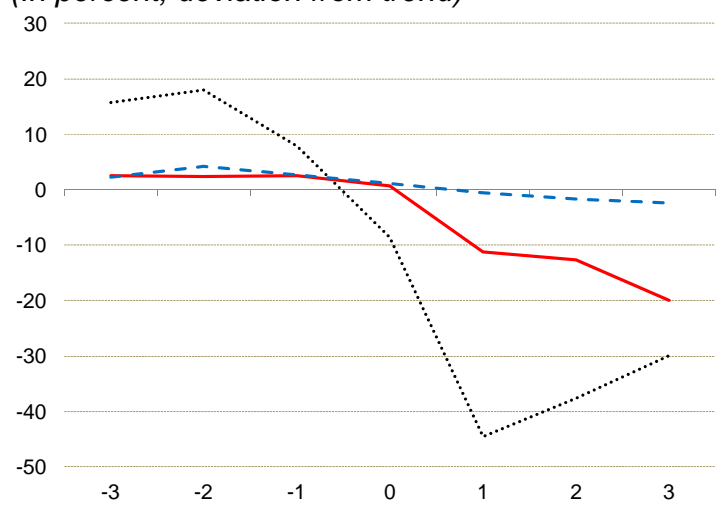

Overall Fiscal Buildup

(In percent of GDP)

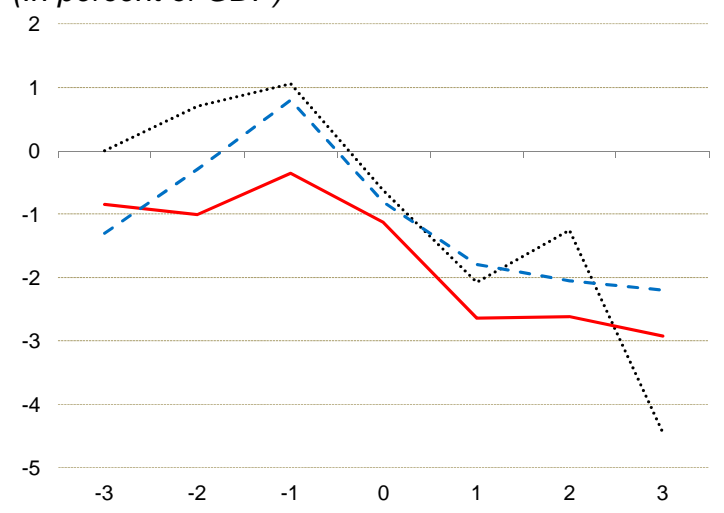

\section{Reserves}

(In percent, deviation from trend)

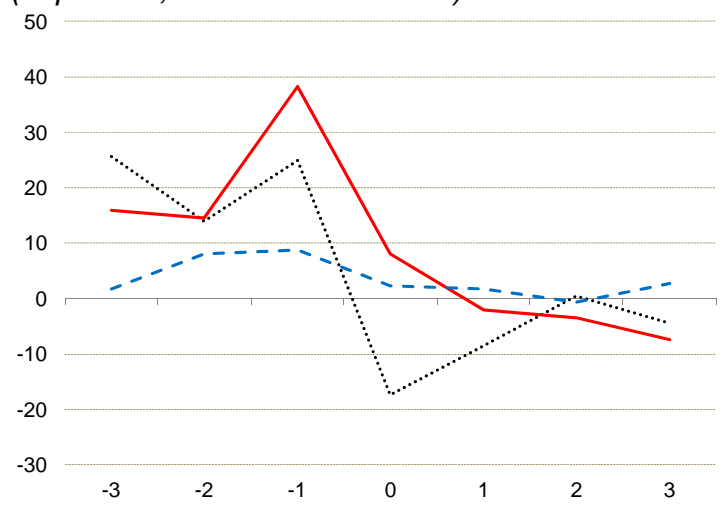

\section{Real Government Consumption}

(In percent, deviation from trend)

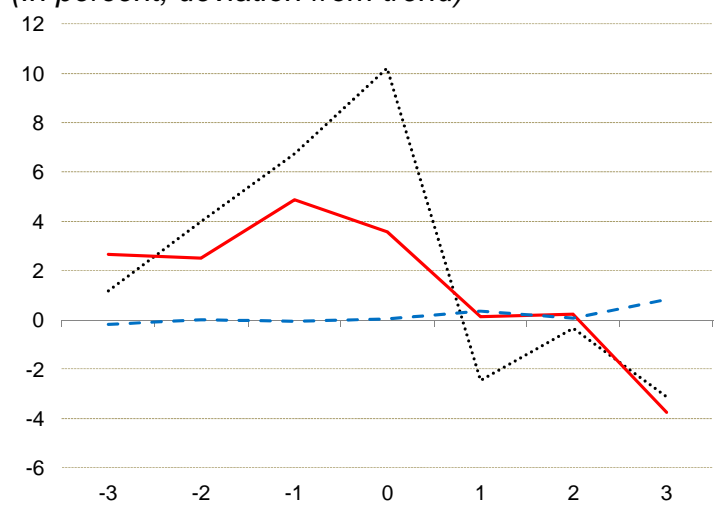

Sources: IMF WEO database; and authors'calculations. 


\section{Figure 12. Credit Booms and Financial Instability}
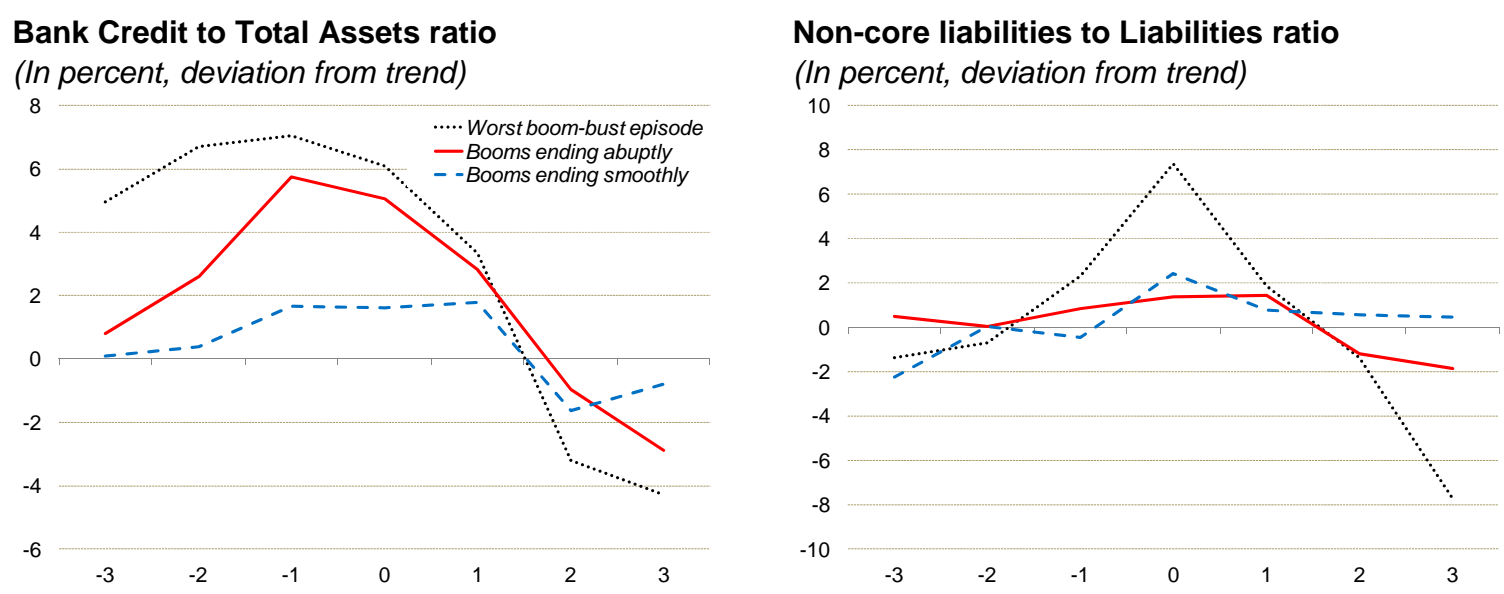

\section{Bank Credit to $\mathrm{M} 2$ ratio}

(In percent, deviation from trend)

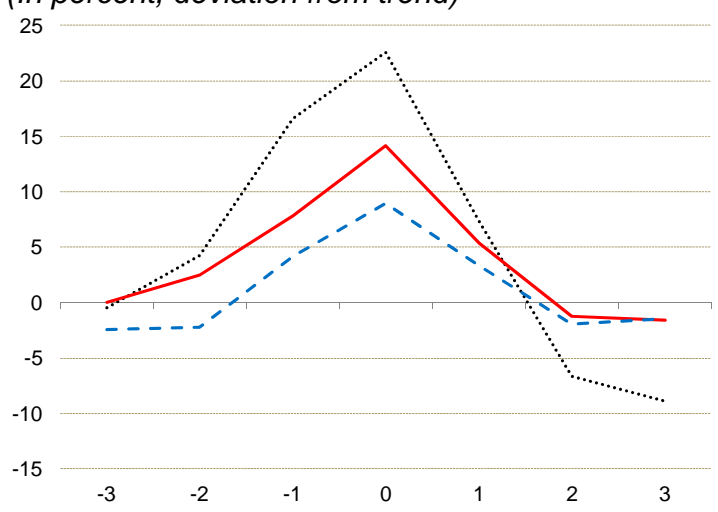

Nonperforming Loans

(In percent of total assets, deviation from trend)

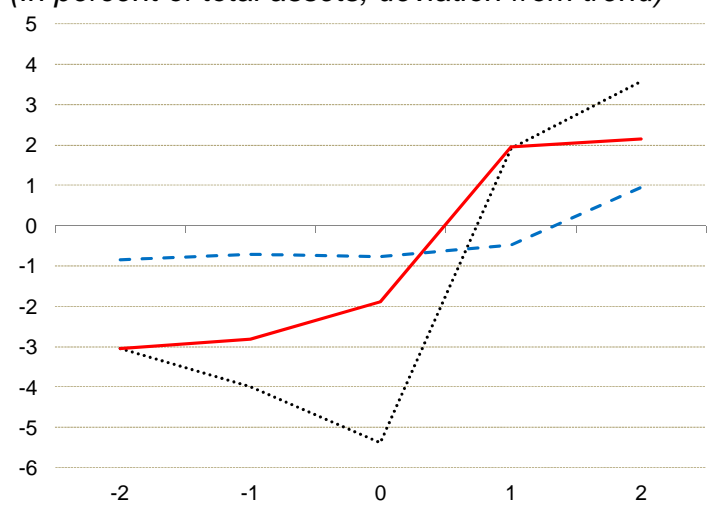

\section{Stock Prices}

(In percent, deviation from trend)

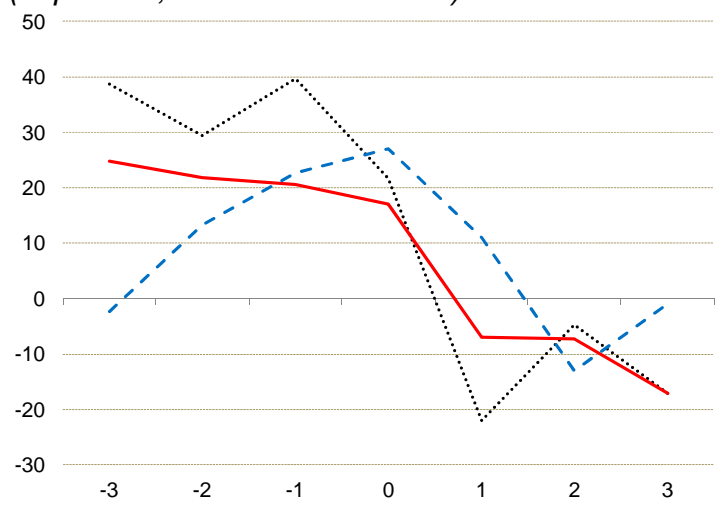

\section{Return on Assets}

(In percent, deviation from trend)

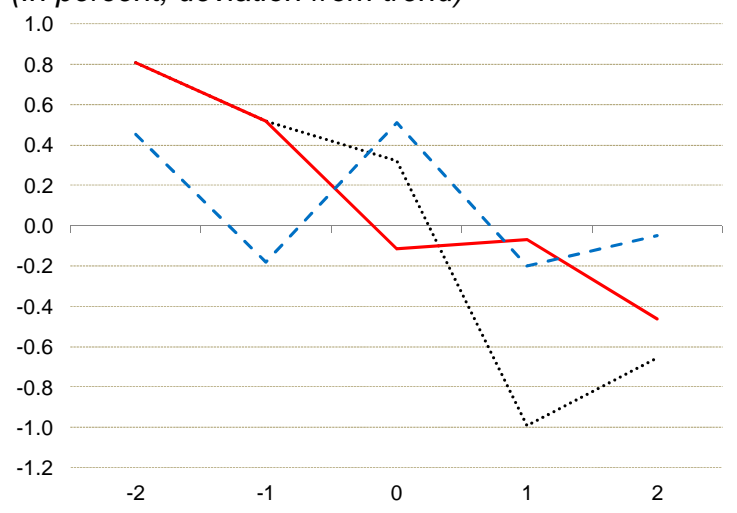

Sources: IMF WEO and IFS databases; Bankscope; Worldscope; and authors' calculations. 
Figure 13. Credit Booms: Corporate Sector

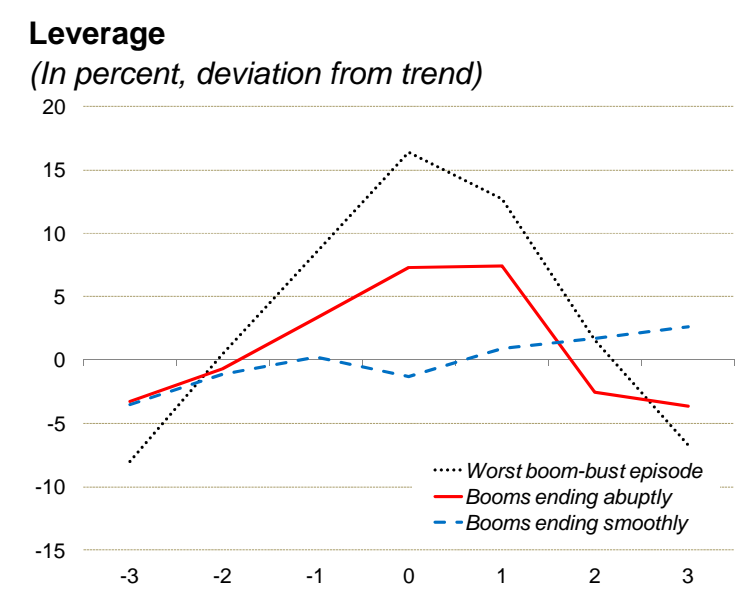

Average Interest Rate

(In percent, deviation from trend)

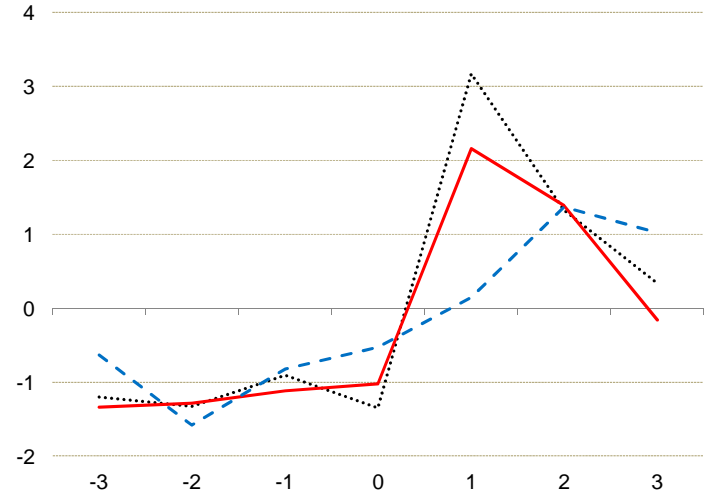

\section{Return on Equity}

(In percent)

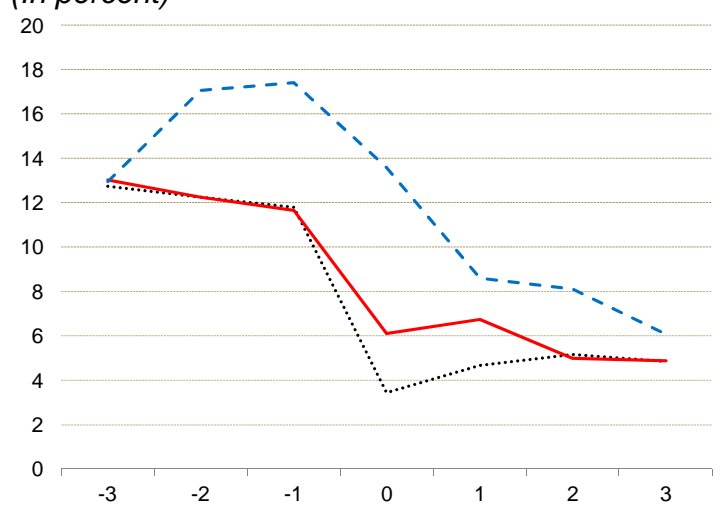

\section{Price to Earnings Ratio}

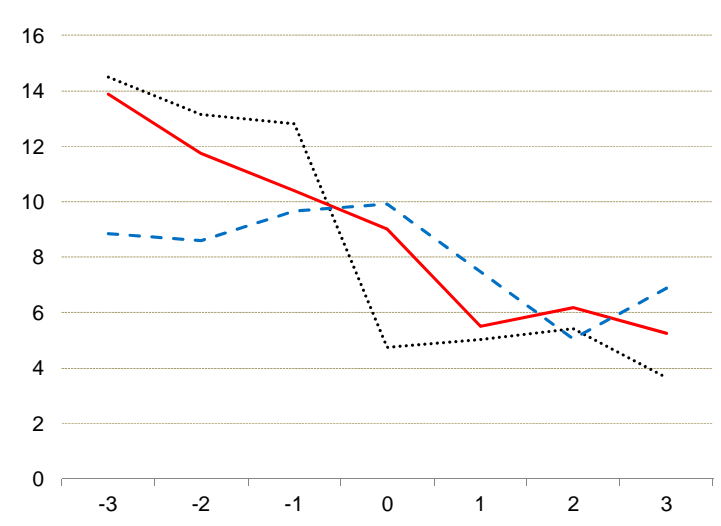

\section{Rajan-Zingales Index}

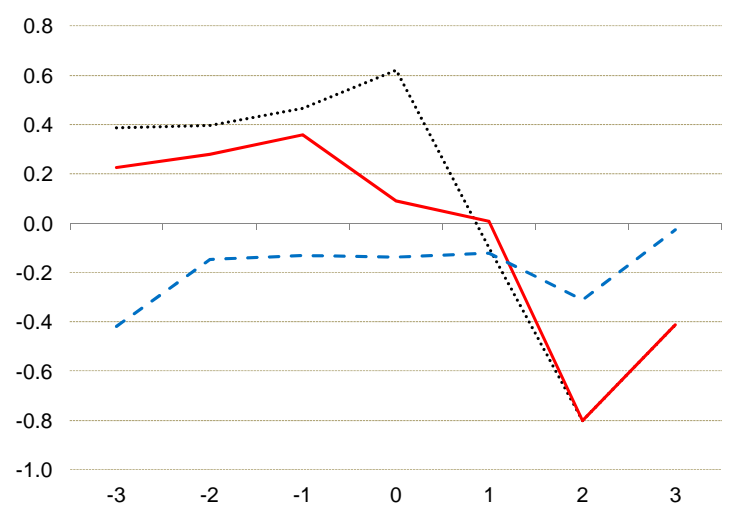

\section{Capital Expenditures}

(In percent, deviation from trend)

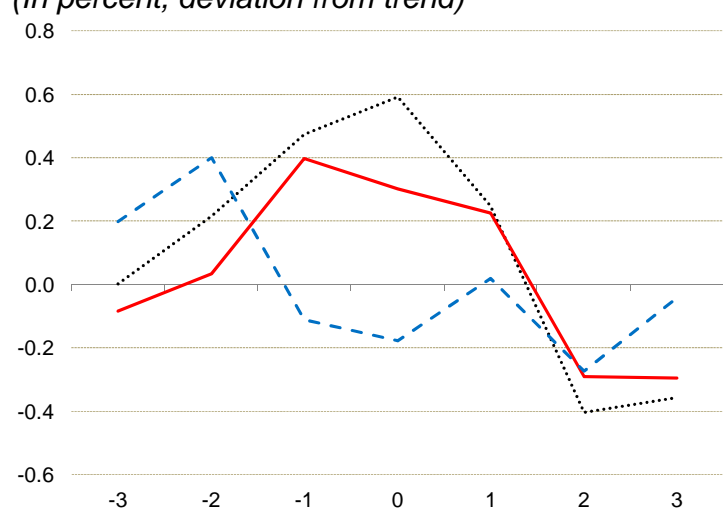

Sources: Worldscope; and authors' calculations. 


\section{Figure 14. Advanced Versus Emerging Economics: Real Sector}

\section{Real Credit}

(In percent, deviation from trend)

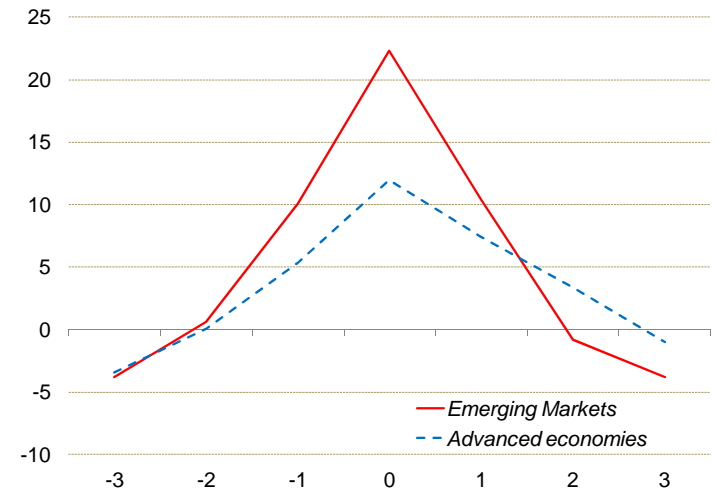

Real Domestic Demand

(In percent, deviation from trend)

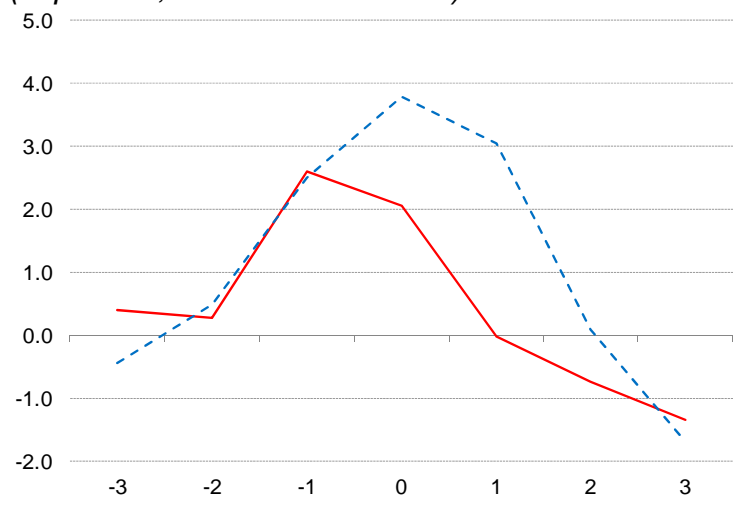

\section{CPI Inflation}

(In percent, deviation from trend)

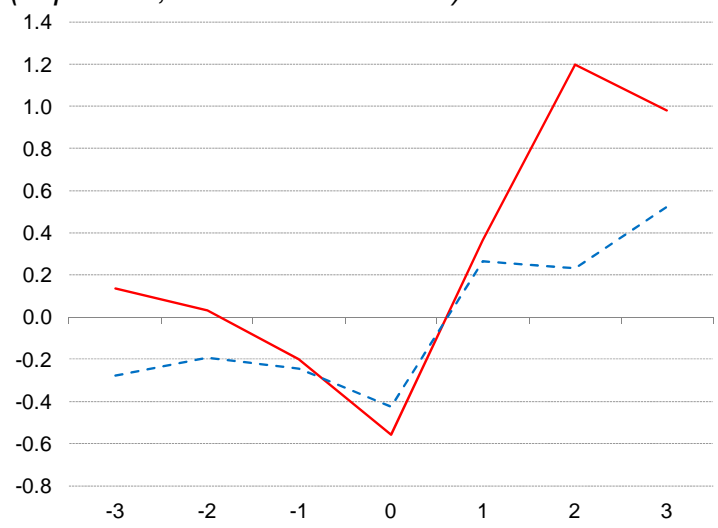

\section{Real GDP}

(In percent, deviation from trend)

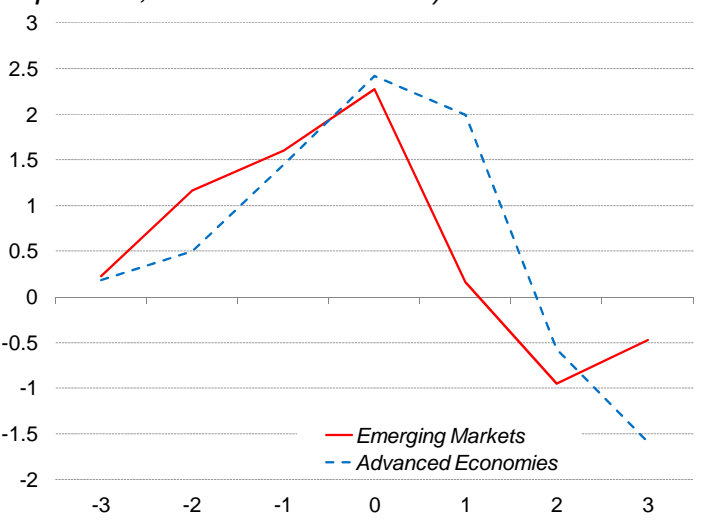

\section{Real Consumption}

(In percent, deviation from trend)

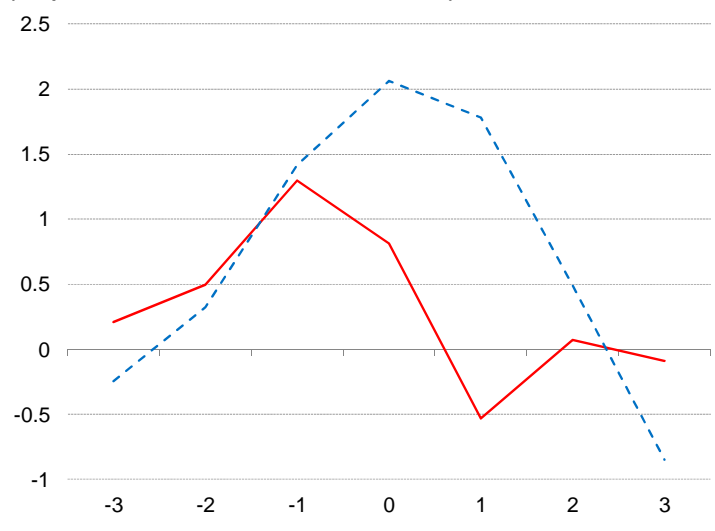

Real Investment

(In percent, deviation from trend)

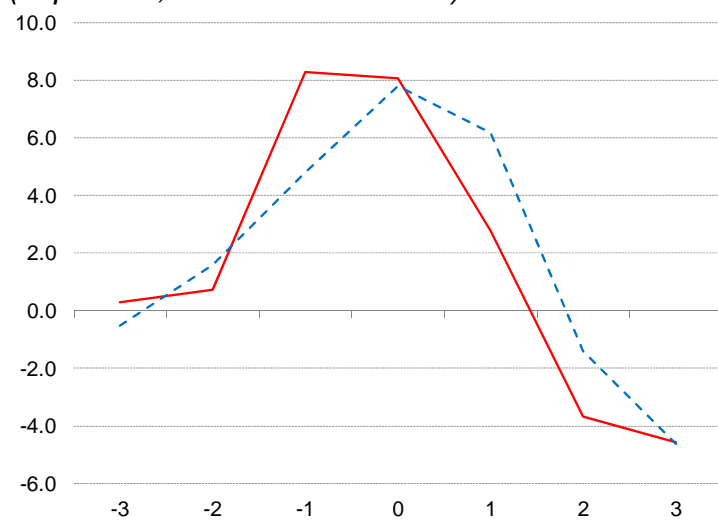

Sources: IMF WEO database; and authors' calculations.' 


\section{Figure 15. Advanced Versus Emerging Economics: Real GDP}

\section{Real GDP}

(In percent, deviation from trend)

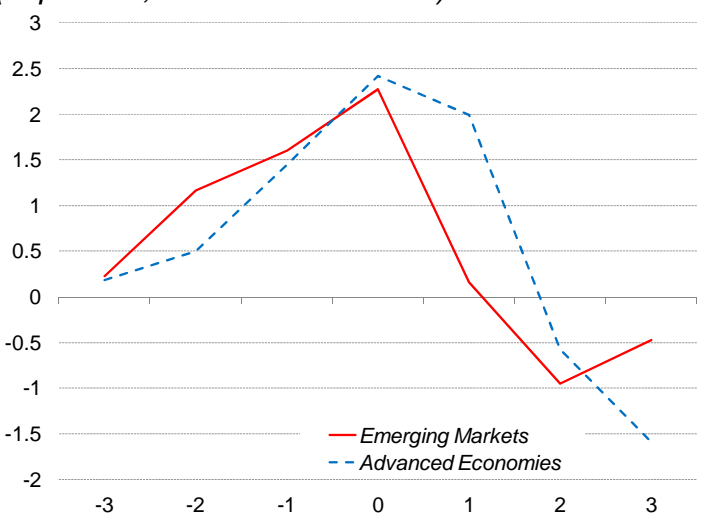

PPP per capita, international dollars

(In percent, deviation from trend)

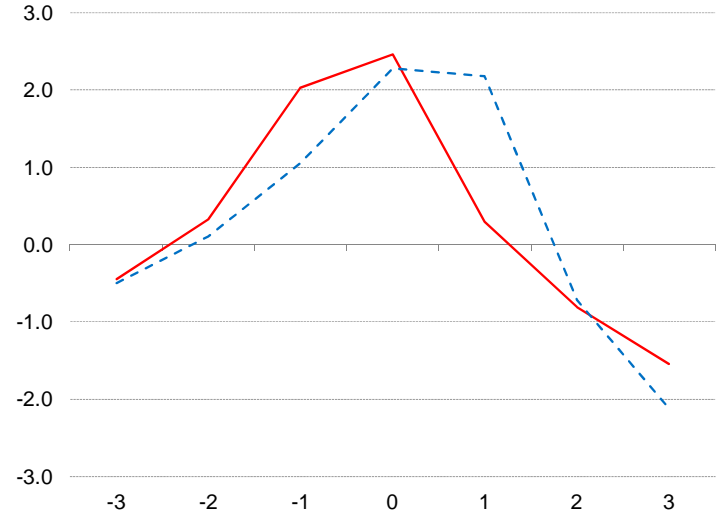

PPP per Capita—Mendoza-Terrones Countries (In percent, deviation from trend)

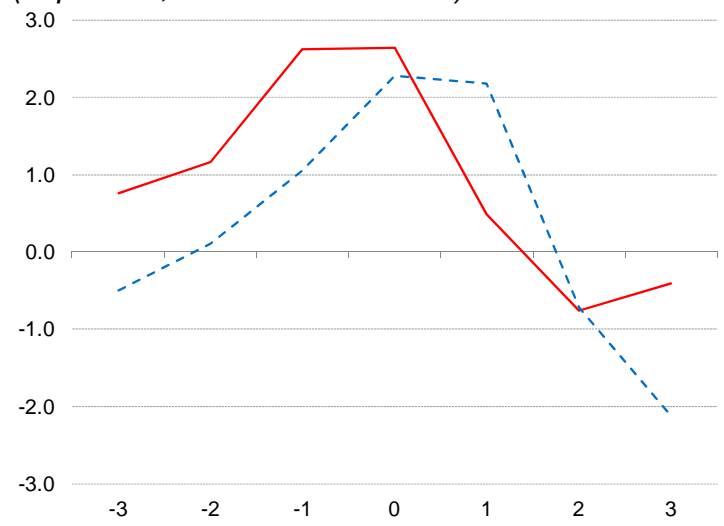

Real GDP (using 1.96 threshold)

(In percent, deviation from trend)

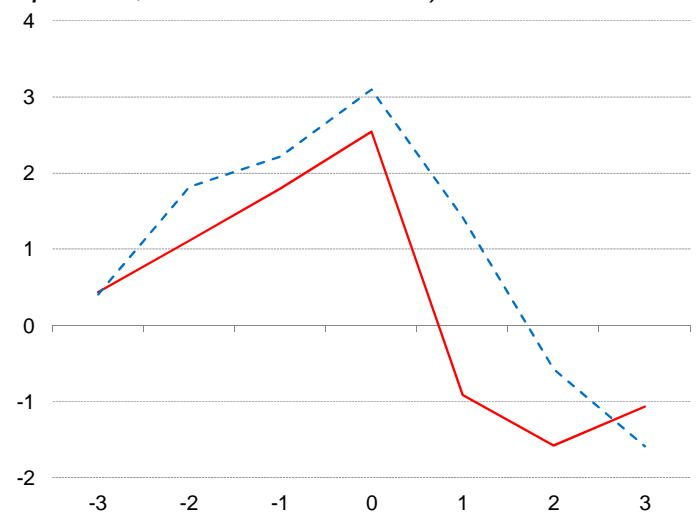

Real GDP Without 2007 booms

(In percent, deviation from trend)

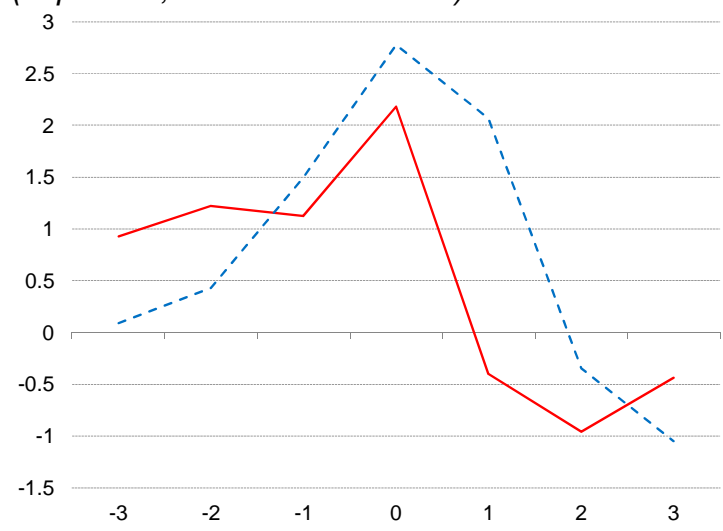

Sources: IMF WEO database; and authors'calculations. 
Figure 16. Advanced versus Emerging Economics: External Sector

\section{Current Account}

(In percent of GDP, deviation from trend)

$$
1
$$

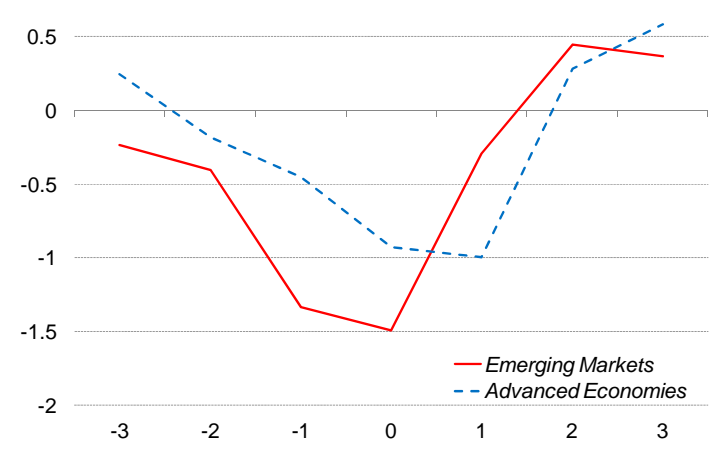

\section{Other Flows}

(In percent of GDP)

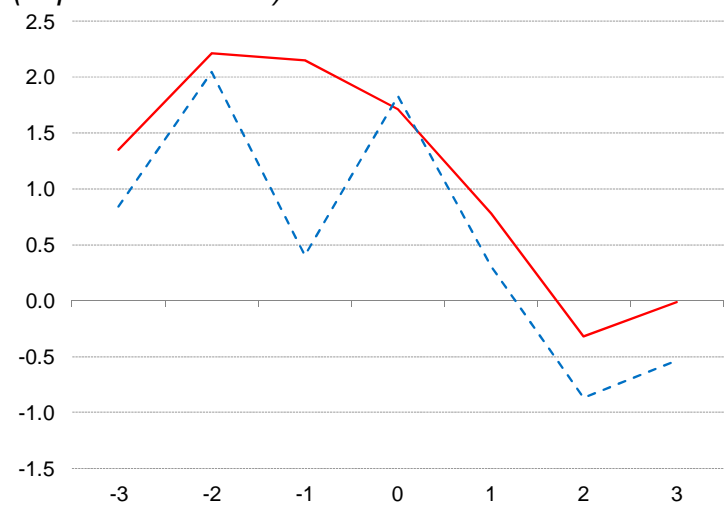

Non-FDI

(In percent of GDP)

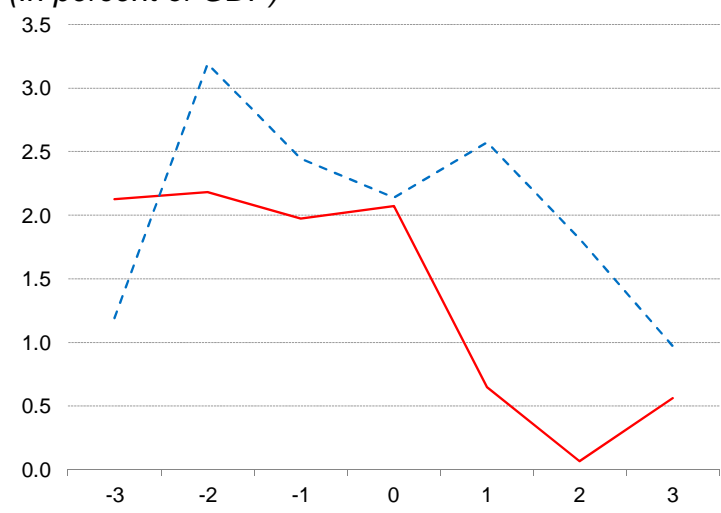

Capital Flows

(In percent of GDP, deviation from trend)

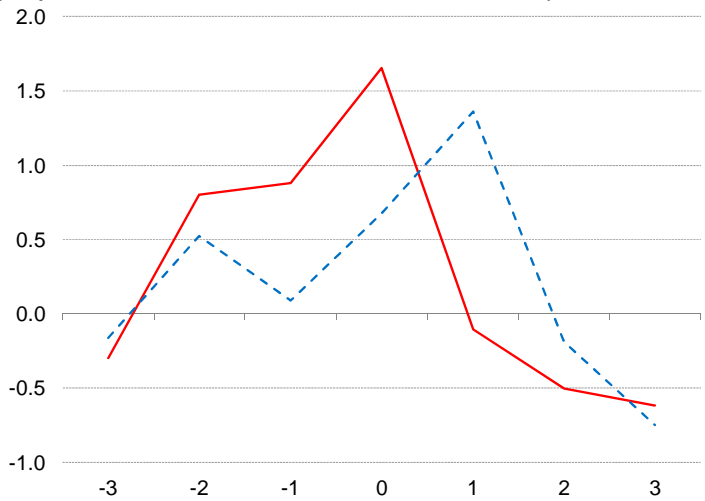

Portfolio Investment

(In percent of GDP)
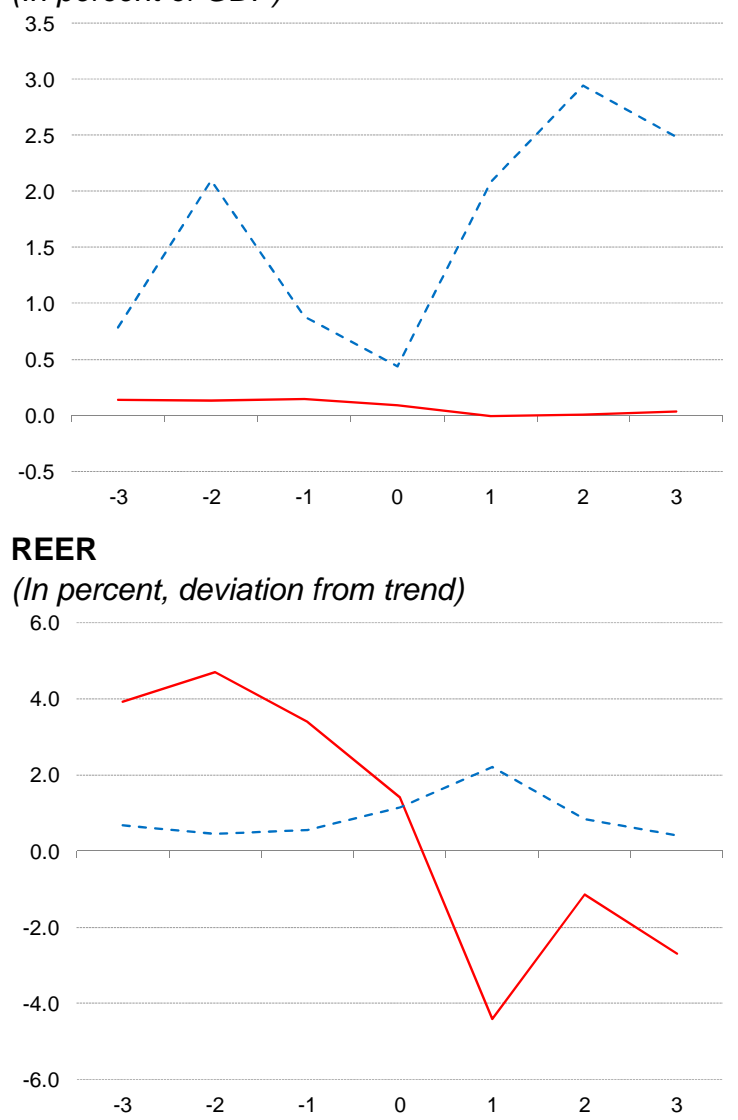

Sources: IMF WEO database; and authors' calculations.' 


\section{Figure 17. Advanced Versus Emerging Economics: The Role of Policies}

\section{Policy Rates}

(In percent, deviation from trend)

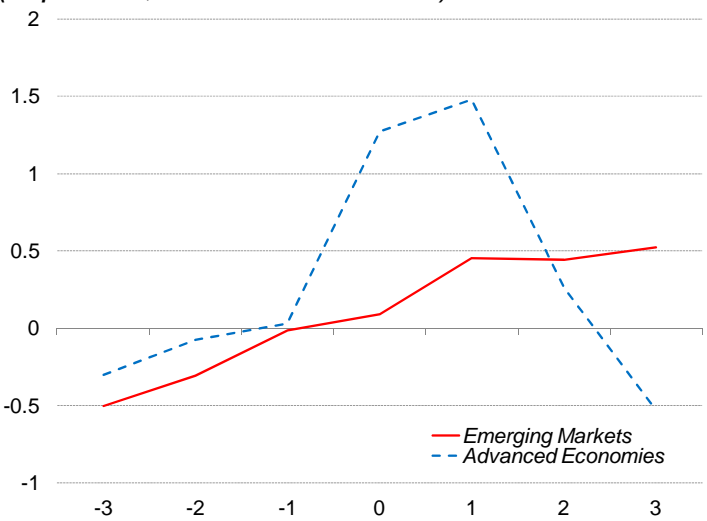

NEER

(In percent, deviation from trend)

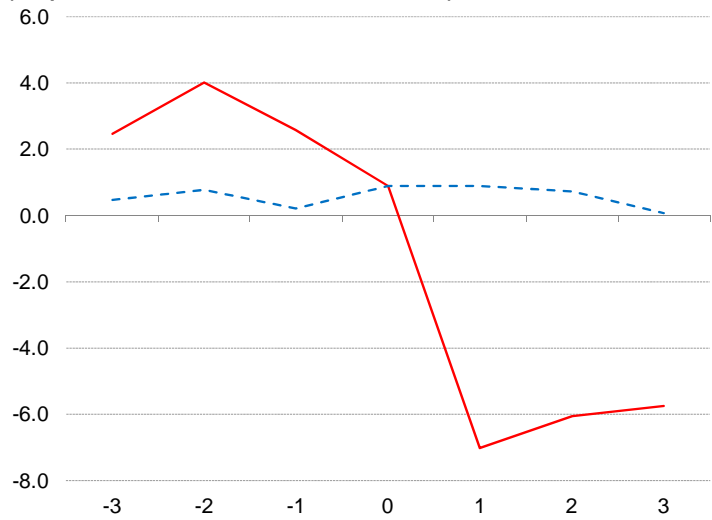

Overall Fiscal Balance

(In percent of GDP, deviation from trend)

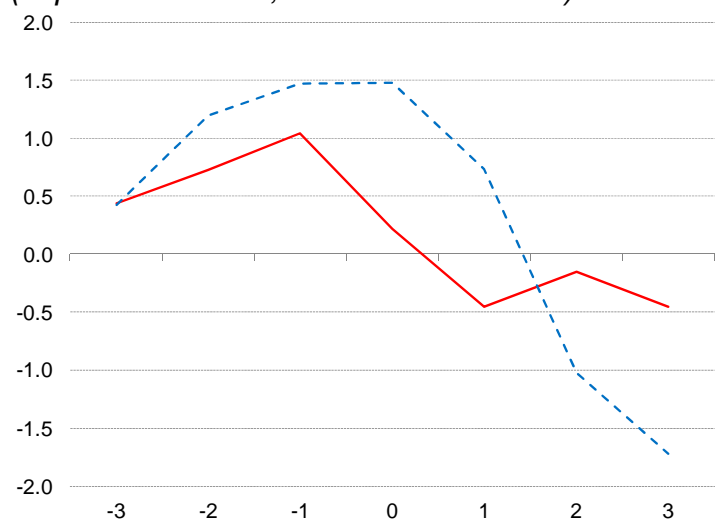

Real Policy Rates

(In percent, deviation from trend)

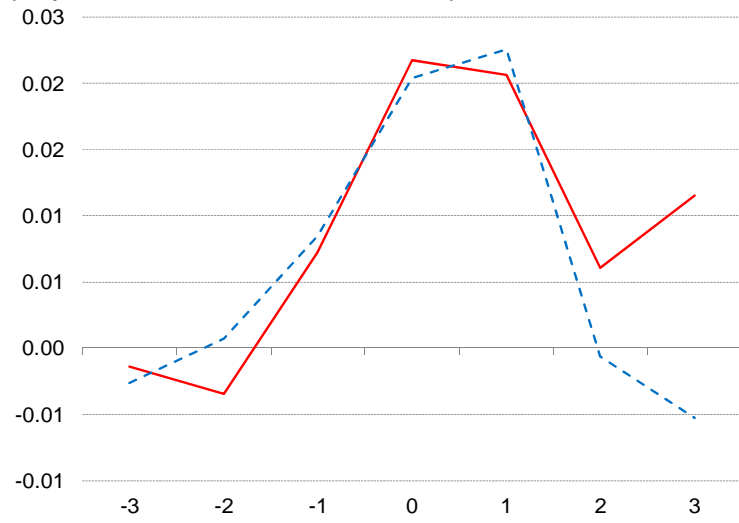

\section{Reserves}

(In percent, deviation from trend)

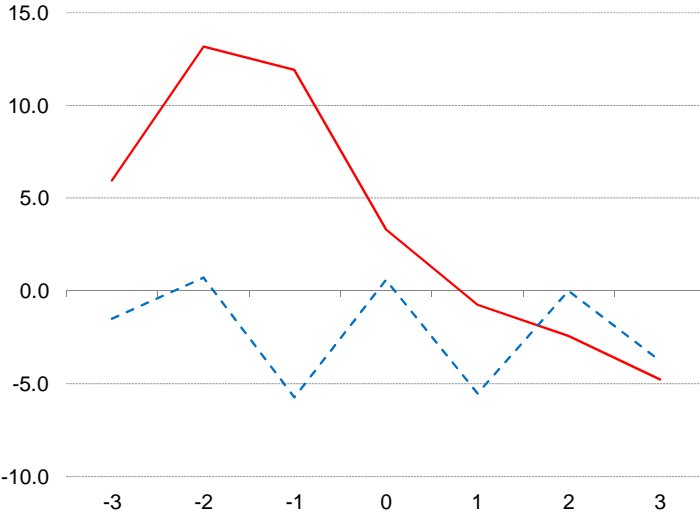

Real Government Consumption

(In percent, deviation from trend)

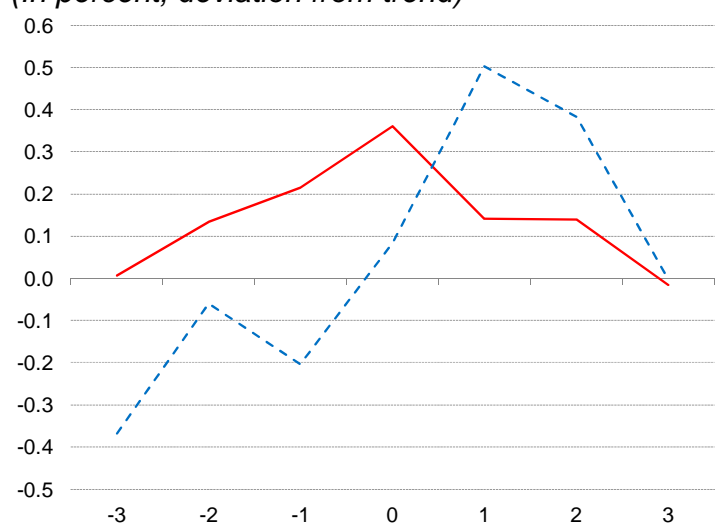

Sources: IMF WEO database; and authors' calculations. 


\section{Figure 18. Advanced Versus Emerging Economics: Credit Booms and Financial Instability}

\section{Bank Credit to Total Assets ratio}

(In percent, deviation from trend)

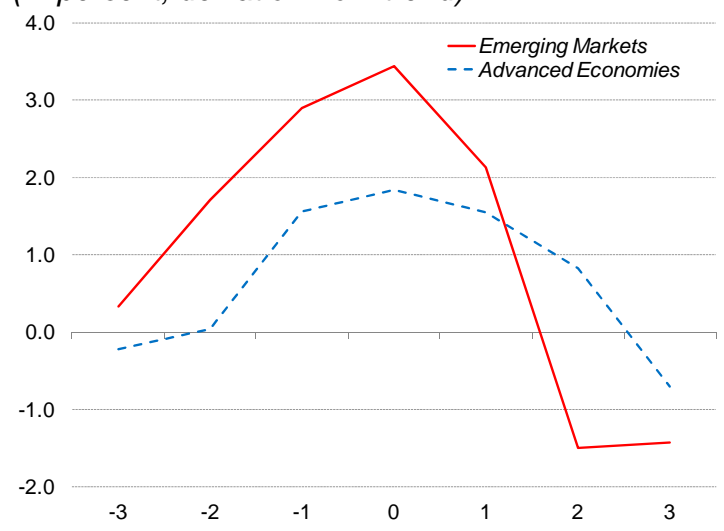

\section{Bank Credit to M2 ratio}

(In percent, deviation from trend)

14.0

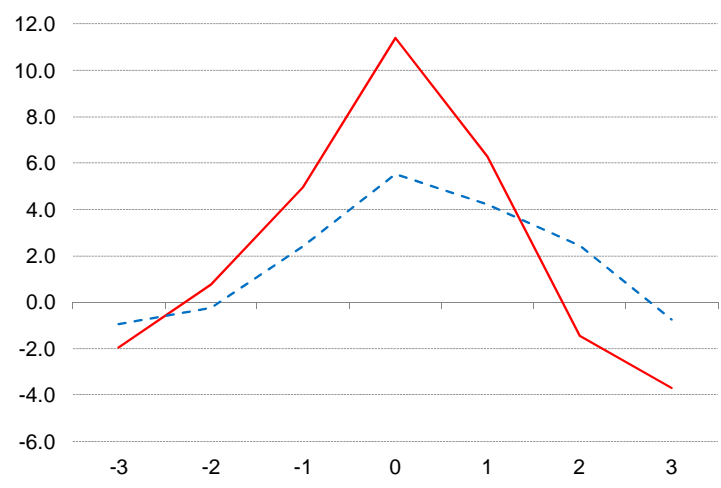

\section{Real House Prices}

(In percent, deviation from trend)

12.0

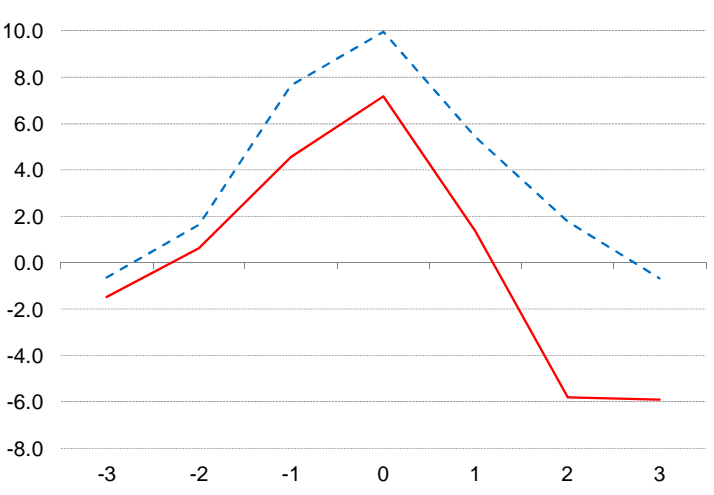

Non-core liabilities to Liabilities ratio

(In percent, deviation from trend)

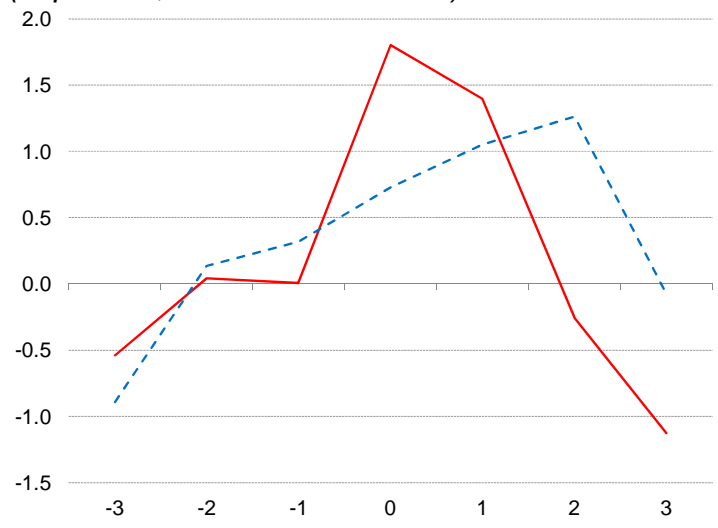

Foreign liabilities to Liabilities Ratio

(In percent, deviation from trend)

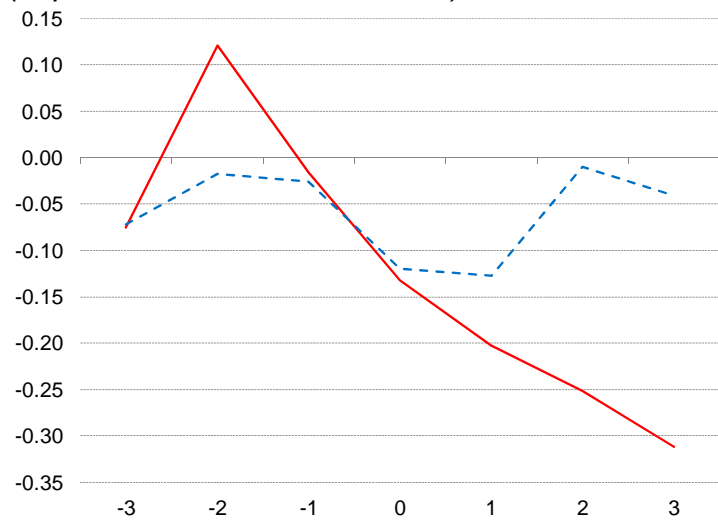

\section{Stock prices}

(In percent, deviation from trend)

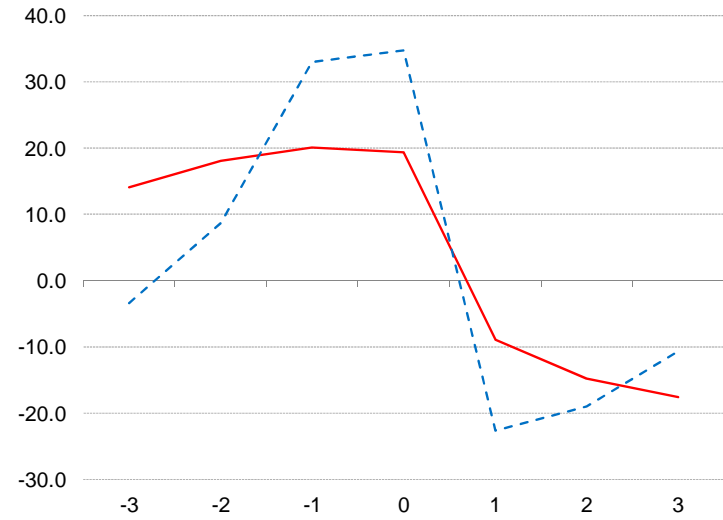

Sources: IMF IFS database; and authors'calculations. 
Figure 19. Advanced Versus Emerging Economics: Corporate Sector

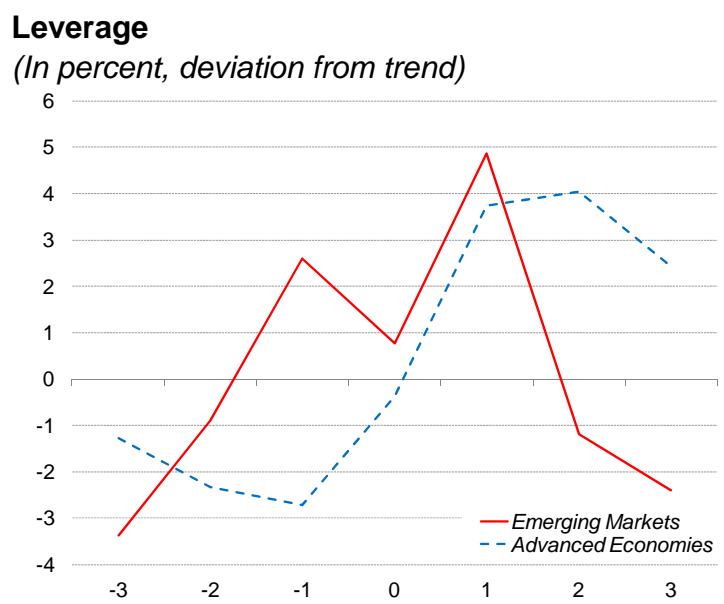

Return on equity

(In percent, deviation from trend)

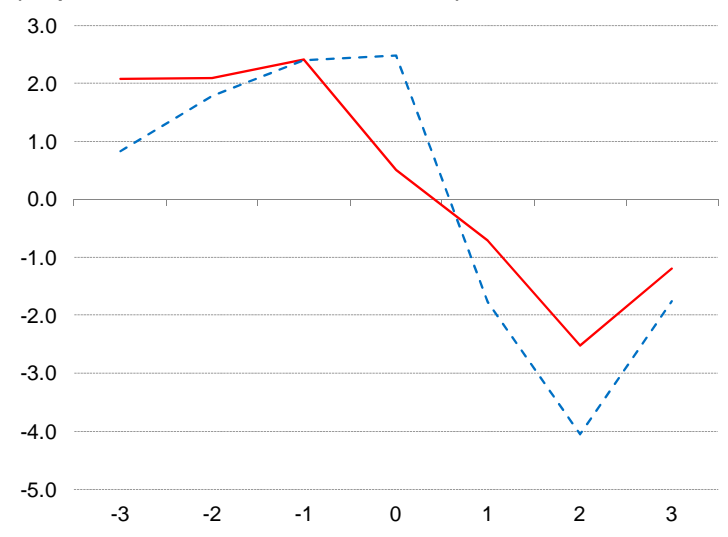

\section{Rajan-Zingales Index}

Average Interest Rate

(In percent, deviation from trend)

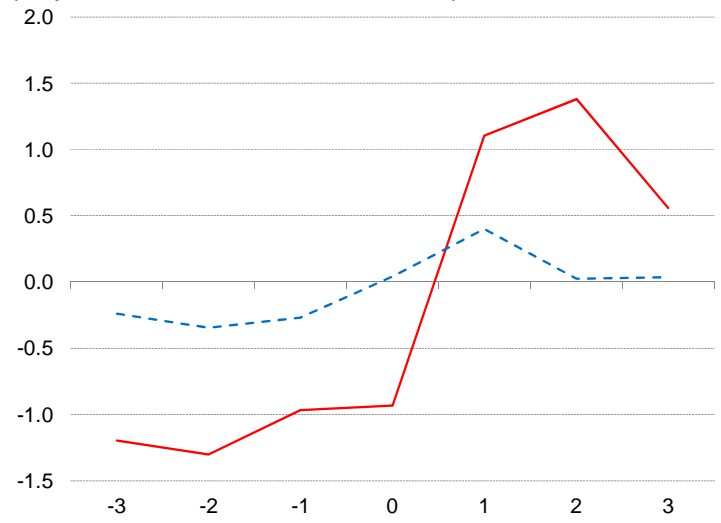

Price to earnings ratio

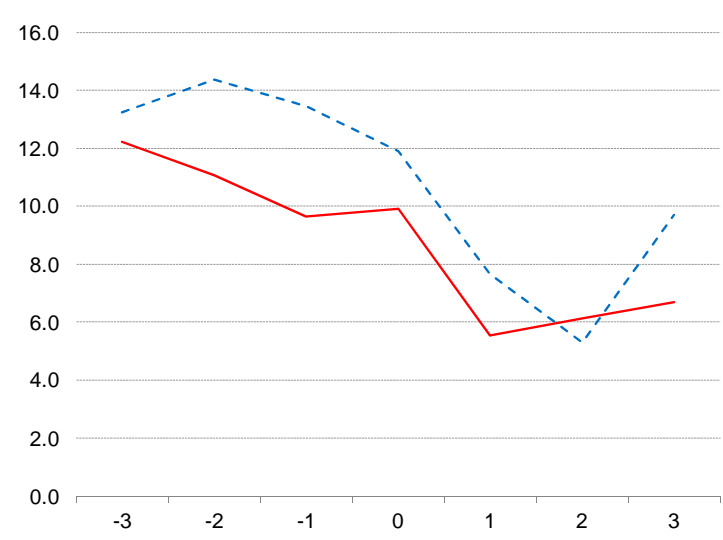

\section{Capital Expenditures}

(In percent, deviation from trend)
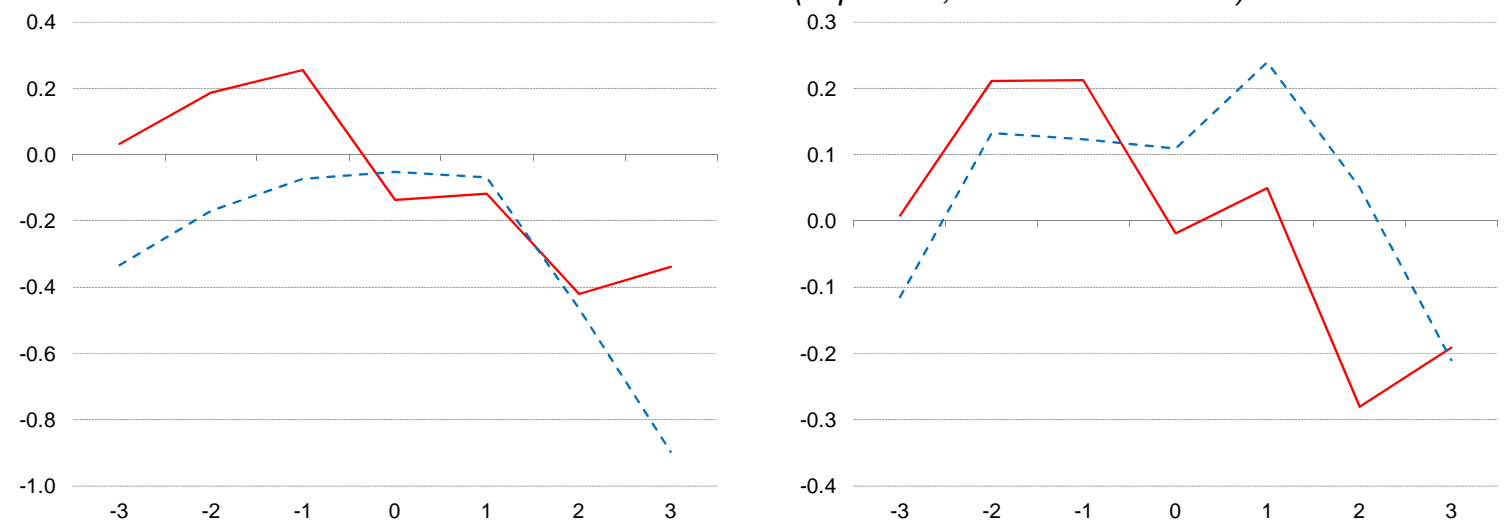

Sources: IMF WEO database; Worldscope; and authors' calculations. 


\section{References}

Abiad, A., G. Dell'Ariccia, and B. Li, 2011, “Creditless Recoveries,” IMF Working Paper 11/58 (Washington: International Monetary Fund).

Bakker, B.B., and, A.M. Gulde, 2010, “The Credit Boom in the EU New Member States: Bad Luck or Bad Policies?” IMF Working Paper 10/130 (Washington: International Monetary Fund).

Barajas, A., R. Chami, R.A. Espinoza, and H. Hesse, 2010, "Recent Credit Stagnation in the MENA Region: What to Expect? What Can Be Done?” IMF Working Paper 10/219 (Washington: International Monetary Fund).

Barajas, A., G. Dell’Ariccia, and A. Levchenko, forthcoming, “Credit Booms: The Good, the Bad, and the Ugly,” IMF Working Paper (Washington: International Monetary Fund).

Bean, C., M. Paustian, A. Penalver, and T. Taylor, 2010, "Monetary Policy after the Fall,” presented at the Federal Reserve Bank of Kansas City Annual Conference, Jackson Hole, Wyoming, September 16, 2010.

Bernanke, B., M. Gertler, and S. Gilchrist, 1999, “The Financial Accelerator in a Quantitative Business Cycle Framework,” in Handbook of Macroeconomics, ed. by J. B. Taylor and M. Woodford, Vol. 1, pp. 1341-393 (The Netherlands: Elsevier Science).

Borio, C. and P. Lowe, 2004, “Securing Sustainable Price Stability: Should Credit Comeback from the Wilderness?” BIS Working Paper No. 157 (Basel: Bank for International Settlements).

Bry, G. and C. Boschan, 1971, Cyclical Analysis of Time Series: Selected Procedures and Computer Programs, (New York: National Bureau of Economic Research).).

Burns, A.F., and W.C. Mitchell, 1946, Measuring Business Cycles (New York: National Bureau of Economic Research).).

Calvo, G., L. Leiderman, and C. Reinhart. (1996). “Inflows of Capital to Developing Countries in the 1990s.” Journal of Economic Perspectives, Vol. 10, No. 2, pp. 123-39.

Calvo, G., A. Izquierdo, and E. Talvi, 2006, "Sudden Stops and Phoenix Miracles in Emerging Markets,” American Economic Review Papers and Proceedings, Vol. 96, No.2, pp.405-10.

Calvo, G.A., A. Izquierdo, and L.F. Mejia, 2004, “On the empirics of Sudden Stops: The Relevance of Balance Sheet Effects,” NBER Working Paper No. 10520 (Cambridge, Massachusetts: National Bureau of Economic Research). 
Cardarelli, R., S. Elekdag, and M.A. Kose, 2007, “Managing Large Capital Inflows,” in World Economic Outlook, October 2007: Globalization and Inequality, World Economic and Financial Surveys (Washington: International Monetary Fund).

Cardarelli, R., S. Elekdag, and M.A. Kose, 2010, “Capital Inflows: Macroeconomic Implications and Policy Responses,” Economic Systems, Vol. 34, No. 4, pp. 333-56.

Claessens, S., M.A. Kose, and M. Terrones, 2011, “Financial Cycles: What? How? When?” IMF Working Paper 11/76 (Washington: International Monetary Fund).

Decressin, J. and M. Terrones, 2011, “Credit Boom-Bust Cycles: Their Triggers and Policy Implications” in World Economic Outlook, October 2007: Slowing Growth, Rising Risks, World Economic and Financial Surveys (Washington: International Monetary Fund).

Dell’Ariccia, G., and R. Marquez, 2006, “Lending Booms and Lending Standards,” Journal of Finance, Vol. 61, pp. 2511-545.

Eichengreen, B., A. Rose, and C. Wyplosz, 1996, “Contagious Currency Crises: First Tests,” The Scandinavian Journal of Economics, Vol. 98, No. 4, pp. 463-84.

Gourinchas, P.-O., R. Valdes, and O. Landerretche, 2001, "Lending Booms: Latin America and the World,” Economia, Vol. 1 (spring), pp. 47-99.

Gertler, M. and N. Kiyotaki, forthcoming, "Financial Intermediation and Credit Policy in Business Cycle Analysis,” Handbook of Monetary Economics.

Harding, D., and A. Pagan, 2002, “Dissecting the Cycle: A Methodological Investigation,” Journal of Monetary Economics Vol. 49, pp. 365-81.

Hodrick, R., and E.C. Prescott, 1997, "Postwar U.S. Business Cycles: An Empirical Investigation,” Journal of Money, Credit, and Banking, Vol. 29, No. 1, pp. 1-16.

Jorda, O., M. Schularick, and A.M. Taylor, 2010, "Financial Crises, Credit Booms, and External Imbalances: 140 Years of Lessons,” NBER Working Paper No. 16567 (Cambridge, Massachusetts: National Bureau of Economic Research).

Kaminsky, G., and C. Reinhart, 1999, “The Twin Crises: The Causes of Banking and Balance-of-Payments Problems,” American Economic Review, Vol. 89, pp. 473-500.

Kaminsky, G.L., C.M. Reinhart, C.A. Végh, 2005, "When It Rains, It Pours: Procyclical Capital Flows and Macroeconomic Policies,” in NBER Macroeconomics Annual 2004, Vol. 19, ed. by M. Gertler and K. Rogoff, pp. 11-82 (Cambridge, Massachusetts: National Bureau of Economic Research).

Kiyotaki, N., and J. Moore, 1997, “Credit Cycles,” Journal of Political Economy, Vol. 105, No. 2, pp. 211-48. 
Kannan, P., 2010, “Credit Conditions and Recoveries from Recessions Associated with Financial Crises,” IMF Working Paper 10/83 (Washington: International Monetary Fund).

Levine, R. 2005, “Finance and Growth: Theory and Evidence,” in Handbook of Economic Growth, ed. by P. Aghion and S. Durlauf (The Netherlands: Elsevier Science).

Mendoza, E. and M. Terrones, 2008, “An Anatomy of Credit Booms: Evidence from Macro Aggregates and Micro Data,” NBER Working Paper No. 14049 (Cambridge, Massachusetts: National Bureau of Economic Research).

Rajan, R.G., and L. Zingales, 1998, “Financial Dependence and Growth,” American Economic Review, Vol. 88, No. 3, 559-86.

Ravn, M.O., and H. Uhlig, 2002, "On Adjusting the Hodrick-Prescott Filter for the Frequency of Observations,” Review of Economics and Statistics, Vol. 84, No. 2, pp. 371-76.

Reinhart, C. and V. Reinhart, 2009, “Capital Flow Bonanzas: An Encompassing View of the Past and Present,” in NBER International Seminar on Macroeconomics (Chicago: University of Chicago Press).

Reinhart, C. and K.S. Rogoff, 2009, This Time is Different: Eight Centuries of Financial Folly (Princeton: Princeton Press).

Shin, H.S. and K. Shin, 2011, "Procyclicality and Monetary Aggregates”, NBER Working Paper No. 16836 (Cambridge, Massachusetts: National Bureau of Economic Research).

Schularick, M. and A.M. Taylor, 2009, “Credit Booms Gone Bust: Monetary Policy, Leverage Cycles and Financial Crises, 1870-2008,” NBER Working Paper No. 15512 (Cambridge, Massachusetts: National Bureau of Economic Research).

Taylor, J.B., 2010, “Macroeconomic Lessons from the Great Deviation,” remarks at the 25th NBER Macro Annual Meeting, May 2010: http://www.johnbtaylor.com/

Terrones, M. and E. Mendoza, 2004, “Are Credit Booms in Emerging Markets a Concern?” World Economic Outlook, pp. 148-166 (Washington: International Monetary Fund).

Tornell, A., and F. Westermann, 2002, “Boom-Bust Cycles in Middle Income Countries: Facts and Explanation,” IMF Staff Papers, Vol. 49, Special Issue, pp. 111-53. 